\title{
STRATEGIC EUROPEAN INTEGRATION SCENARIOS OF UKRAINIAN AND POLISH RESEARCH, EDUCATION AND INNOVATION SPACES
}

\author{
Yurii Kharazishvili, Aleksy Kwilinski, Henryk Dzwigol, and Viacheslav Liashenko
}

\begin{abstract}
A comprehensive study was conducted in the direction of research and institutional support and comparison with the nearest neighbour - Poland, to determine the current state and justify strategic scenarios for Ukraine's integration into the research, educational and innovation spaces of the EU as a source of proactive sustainable innovative development. Analysis of the use of foresight technology to determine the possible future, create the desired image of the future and determine strategies to achieve it using methods developed in various research areas revealed that its application makes sense in determining long-term factors, trends and directions of national economies. That is, in foresighting, in contrast to forecasting, the emphasis is made on qualitative rather than quantitative results, which does not provide the expected targeted policy of the state, because it does not give clear, concrete results of actions - quantitative strategic benchmarks, monitoring which would control the process of these areas' development. The disadvantages of foresighting methods that limit its application are identified. Scientific substantiation of strategic scenarios of European integration of Ukrainian and Polish research, education and innovation spaces is based on the concept of sustainable development, which is grounded on applied systems theory, management theory and economic cybernetics and comprises the stages of identifying and strategizing. Identification is carried out taking into account the definition of the safe existence boundaries and simultaneous norming and integrated convolution of indicators and thresholds of education and innovation. Comparison on one scale of integrated indices of education and innovation makes it possible to carry out the goal-setting stage, identify possible strategic development scenarios and build the desired development trajectories, i.e., to implement the principle of strategizing "the future is determined by the trajectory into future." Thus, knowledge of the desired values of integrated indices in each year makes it possible, through their decomposition by the method of adaptive regulation from the management theory, to justify the values of indicators that provide the desired growth trajectory and achieve certain goals of research, educational and innovative spaces of Ukraine and Poland.
\end{abstract}

Keywords: education, innovation, boundaries of safe existence, integrated index, development trajectories, strategic scenarios

JEL Classification: COO, E00, O00 


\section{Authors:}

Yurii Kharazishvili

Institute of Industrial Economics of the National Academy of Sciences of Ukraine, Zheliabov St., 2, Kyiv, Ukraine, 03057

E-mail:yuri_mh@ukr.net

https://orcid.org/0000-0002-3787-1323

\section{Aleksy Kwilinski}

The London Academy of Science and Business, 120 Baker Street, London, United Kingdom, W1U 6TU E-mail: a.kwilinski@london-asb.co.uk https://orcid.org/0000-0001-6318-4001

\section{Henryk Dzwigol}

Silesian University of Technology, 26-28 Roosevelt Street, Zabrze, Poland, 41-800

E-mail: henryk.dzwigol@poczta.fm

https://orcid.org/0000-0002-2005-0078

\section{Viacheslav Liashenko}

Institute of Industrial Economics of the National Academy of Sciences of Ukraine, Zheliabov St., 2, Kyiv, Ukraine, 03057

E-mail: slaval_aenu@gmail.com https://orcid.org/0000-0001-6302-0605

Citation: Kharazishvili, Y., Kwilinski, A., Dzwigol, H., \& Liashenko, V. (2021). Strategic European Integration Scenarios of Ukrainian and Polish Research, Education and Innovation Spaces. Virtual Economics, 4(2), 7-40. https://doi.org/10.34021/ve.2021.04.02(1) 


\section{Introduction}

The fact of signing the Association Agreement between Ukraine, on the one hand, and the European Union, the European Atomic Energy Community and their Member States, on the other hand, amending the Constitution of Ukraine to determine the strategic course of Ukraine to become a full member of the European Union, prove that Ukraine has demonstrated its intentions and readiness to access into the European space and the system of formal EU institutions, to adopt their rules, norms and practices, and to become an integral part of the European community. This choice provides Ukraine with significant advantages, one of which is the opportunity to establish a real partnership with EU member states in building common research, education and innovation spaces as a basis for ensuring economic development on innovative grounds.

Discussions on the ways, directions and tools of Ukraine's integration into the European community are ongoing, and in recent years, due to objective reasons, have intensified significantly. Traditionally, researchers of European integration issues focus on political and legal, socio-political, security, economic, financial and investment, foreign trade, social and labour, migration and social and communication aspects. Much less attention is paid to the research, educational and innovative components of Ukraine's European integration and their quantitative measurement. The potential for intensifying the processes of Ukraine's integration of the EU's research, educational and innovation spaces is underestimated, and its implementation should be considered as one of the key areas of the strategy to ensure its European vector.

Therefore, conducting a comprehensive study in the direction of research and institutional support and comparison with the nearest neighbour - Poland, to determine the current state and justify strategic scenarios of Ukraine's integration into research, educational and innovation spaces of the EU as a source of sustainable innovation is relevant and timely.

Thus, the purpose of the article is to identify, to carry out a comparative analysis and scientific substantiation of strategic scenarios of Ukrainian and Polish research, education and innovation spaces of European integration of Ukraine and Poland according to the modern methodology of identification and strategizing in the security dimension in the medium-term perspective.

\section{Literature Review}

Integration processes in research, education and innovation spheres are the subject of research by many scholars and experts. A significant number of analytical materials and research papers is devoted to the common EU policy on education, research and technology, cooperation under the program "Horizon 2020", the development of interstate and crossborder cooperation (Trippl, 2013; Radosevic \& Stancova, 2017; Makkonen \& Rohde, 2016; Marek et al., 2017; Chessa et al., 2013, Kharazishvili et al., 2021a; 2021b). 
The attention of Ukrainian scientists to the issues of Ukraine's integration into the European research, educational, innovation - spaces was uneven in time and volume. The first wave of research was devoted to the integration of higher education in Ukraine into the European educational space in terms of joining the Bologna Process and solving problems of ensuring European standards of education quality and academic mobility. The following publications reveal the current state, problems and ways of modernizing higher education in the context of the Bologna process, areas of improvement of legal support for Ukraine's integration into the European educational space, development of university science, participation of Ukrainian higher education institutions in European educational and research programs, and other issues of developing international academic cooperation (Vashchuk, 2011; Khan \& Slyusarenko, 2016; Lugovyi \& Talanova, 2017; Opanasyuk, 2017; Kraevska, 2014).

At the present stage, the scientific search for promising ways of innovative and research and technical development of Ukraine and Poland and the improvement of the research space in the context of European integration processes has intensified. Relevant research is carried out by scholars of leading research institutions of the National Academy of Sciences of Ukraine, as well as individual representatives of university science and experts: (Geets et al., 2015; Haustov, 2018; Egorov, 2016; Matyushenko et al., 2017; Borshchevsky et al., 2017; Babiy, 2015; Lyashenko \& Pidorycheva, 2019).

The abovementioned works consider the role and resources of international research and technical programs in stimulating the development of research, technical and innovative activities in Ukraine, the need to develop a system of indicators of innovation for Ukraine according to EU methods, priorities for research system, problems of forming a roadmap for Ukraine to access the European research space and expected results, prospects for creating a new research and innovation infrastructure, relevant legal framework, the role of clusters as a tool for integration and providing the competitive advantage in the European innovation space, research, education and investment and innovation potential for cross-border cooperation with relevant recommendations and proposals.

At the same time, it should be noted that Ukraine lacks a systematic approach to scientific elaboration and formation of the Strategy of Ukraine's integration into the research, education and innovation spaces of the EU. Meanwhile, no paper considers proposals for its own list of indicators and its own calculation of the current level of research, education and innovation spaces of European integration. Despite the attractive title of the article (Egorov, 2016) on the system of complex indicators for assessing research, technical and innovation activities in the context of European integration processes, the system of indicators itself is not provided, despite the sound reasoning behind the need to develop its own system of indicators for a particular country.

In addition, it is necessary to note the research related to sustainability in economic development, as well as the development of artificial intelligence in the information economy (Aleksander et al., 2020; Arefieva et al., 2021; Boiko et al., 2019; Bogachov et al., 2020; Borychowski et al., 2020; Chygryn et al., 2020; Cyfert et al., 2020; 2021; Czakon et al., 2020; 
Czyżewski et al., 2020a; 2020b; Dalevska et al., 2019; Dementyev \& Kwilinski, 2020; Dementyev et al., 2021; Dyduch, 2019a; 2019b; Dzwigol, 2016; 2019a; 2019b; 2020a; 2020b; 2021a; 2021b; Dzwigol \& Wolniak, 2018; Dzwigol \& Dźwigoł-Barosz, 2018; 2020; Dzwigol et al., 2019a; 2019b; 2019c; 2020a; 2020b; Furmaniak et al., 2018; 2019a; 2019b; Gorynia et al., 2019; Gorynia, 2019; Kaźmierczyk \& Chinalska, 2018; Kharazishvili et al., 2020; 2021a; 2021b; Khrapkina et al., 2021; Klimas et al., 2020; Koibichuk et al., 2021; Kondratenko et al., 2020; Kuzior et al., 2019; 2021; Kwilinski, 2018a; 2018b; 2019; Kwilinski et al., 2019a; 2019b; 2019c; 2019d; 2019e; 2019f; 2020a; 2020b; 2020c; 2020d; 2020e; 2021; Kwilinski \& Kuzior, 2020; Kyrylov et al., 2020; Lakhno et al., 2018; Lyulyov \& Pimonenko, 2017a; Lyulyov \& Shvindina, 2017b); Lyulyov et al., 2018; 2020a; 2020b; 2021; Mlaabdal et al., 2020; Miskiewicz, 2018; 2019; 2020a; 2020b; Melnychenko, 2020; 2021; 2019; Miśkiewicz \& Wolniak, 2020; Pająk et al., 2016; 2017; Pimonenko \& Lyulyov, 2019; Polcyn \& Czyżewski, 2016; Prokopenko \& Miskiewicz, 2020; Saługa et al., 2020; Savchenko et al., 2019; Shkodina et al., 2020; Tkachenko et al., 2019a; 2019b; 2019c; 2019d; 2019e; Trąpczyński et al., 2019; Vatamanyuk-Zelinska \& Melnychenko, 2020; Zastempowski et al., 2020). The strengthening role of these aspects makes a certain trend when considering the issues of innovation space in the context of integration processes.

The main tool for measuring the innovative development of the European Union is the European Innovation Scoreboard (EIS), for which the measurement system has been significantly revised since 2017. The new EIS measurement system is represented by four groups of indicators, including 10 innovative measurements and 27 various indicators. (European Innovation Scoreboards, 2017):

- "framework conditions" cover the main factors of innovation activity that are external to the firm, and three innovative aspects: human resources, attractive research systems, as well as the innovation environment;

- "investment" includes public and private investment in research and innovation and covers two aspects: funding and support, as well as firms' investment;

- "innovation activity" covers innovation efforts at the firm level, grouped by three innovation dimensions: innovators, connections and intellectual assets.

- "impact" covers the sway of companies' innovation on two innovative aspects employment and trade effects.

The use of a special methodology allows calculating Summary Innovation Index (SII) (EIS 2020 Methodology Report) for each country: after calculating each of the 27 indicators, the data undergo a ration setting process in order to translate the variation of normalized indicators in the range from 0 to 1 . Standardization is carried out by the method of "scope of variation", for which the minimum and maximum values of indicators are calculated. After normalization of the data, the arithmetic mean value of the indicators is found, which forms a summary innovation index - SII, and then its relative value to the EU SII as a percentage.

There are a number of remarks on this methodology. Regarding normalization by the method of "scope of variation": if the minimum values are approaching or equal to "0", the normalized values very well reproduce the dynamics of the normalized indicators. However, with a 
significant deviation of the minimum value of the indicator from " 0 ", the dynamics of the normalized indicator increasingly deviates from the display of the output indicator dynamics, simulating not its dynamics, but the dynamics of its range transformation, which is not the same. Therefore, the change in the dynamics of the normalized indicators leads to a change in the factor load and, as a consequence, to a change in the weight coefficients and, thus, a distortion of the integrated index dynamics.

It is difficult to imagine that all indicators have the same effect on the integral index (1/27); this is a very significant simplification that does not correspond to reality. Therefore, a formalized definition of weight values is required. Expert estimates are full of subjectivity and do not exclude fundamental errors. Moreover, weight values cannot be constant - they are dynamic. "...Significant changes in the political and foreign economic situation lead after some time to radical changes in empirical estimates of econometric relationships, which, in turn, leads to changes in weight coefficients" (Kharazishvili, 2019). Otherwise, such an estimate of the SII index will reflect the average temperature in the hospital. In addition, the lack of a formalized definition of the limits of safe existence for each indicator - a vector of threshold values, leads to an artificial distribution of gradations of the integrated index (innovative leaders, strong innovators, moderate innovators, modest innovators) instead of scientifically grounded division of the integrated index range on optimal, pre-crisis, crisis and critical areas for which there exist scientifically grounded approaches. The impossibility of comparing the results of calculations for each year indicates the imperfection of the evaluation methodology.

Regarding the composition of EIS indicators, out of 27 indicators, 22 are resource components that characterize the capacities of individual resources for innovation in the country. That is, the external signs of innovation activity are considered, which, unfortunately, do not give an idea of how these external signs affected (if at all) the final result of economic growth or socioeconomic development. Innovative potential, if it is not realized in the final product (in this case - in the resulting indicators of socio-economic development) can remain only a potential for a long time. Speaking in the language of mathematics, the availability of innovative potential or external signs of innovative activity to determine the level of innovative development is a necessary but insufficient condition.

The resulting EIS indicators, of which there are only 5, are divided into two groups: the impact on employment and the impact on sales. Unfortunately, 2 employment indicators can also be classified as resource, because an increase in employment is a condition (not always necessary) to increase the result, not the result itself. Thus, we can consider the following as resulting innovation indicators: medium and high-tech exports of production, exports of knowledge-intensive services, sales of products new for the market and innovative products new for companies.

According to the authors of this article, this resulting list of indicators lacks the most important - the indicator of scientific and technological progress (STP), recognized worldwide as the most important factor in qualitative changes in the economic system, which depends on many factors: technical and technological and organizational managerial innovation, efficiency of 
using resources, models to organize production of goods and services, existing tariffs for energy and resources, the level of labour force qualification, the share of wages in output, research and development costs, costs of innovation, education costs, legal environment and others.

Therefore, it is very important to determine how all resource indicators - external signs of innovation, affected the rate of STP, i.e., what part of the country's GDP growth is due to the growth of the country's realised innovative potential, along with other factors.

Moreover, there is no considering the methodology of bringing the lagging countries closer to the optimal levels of educational and innovative spaces of the EU, that is, the methodology of strategizing, at all.

\section{Methodology}

Research in determining the level of research, educational and innovative spaces of European integration consists of several stages of the "concept of sustainable development" (Kharazishvili, 2019):

Determining the structure and system of indicators. This stage involves detailing the components and their indicators, forming the dynamics of indicators, identifying their affiliation to stimulants ( $S$ - increase of which is desirable), or de-stimulators ( $D$ - decrease of which is desirable).

Defining the boundaries of safe existence is the most important step in determining the level of security. A systematic study of the problem of sustainable development from the standpoint of security should include defining the boundaries of safe living conditions of the system, without the knowledge of which it is impossible to protect the vital interests of security subjects. That is why for each indicator it is necessary to determine the vector of threshold values: lower critical $\left(x_{\kappa p}^{u}\right)$; lower threshold $\left(x_{n o p}^{u}\right)$; lower optimal $\left(x_{o n m}^{H}\right)$; upper optimal ( $\left.x_{\text {onm }}^{B}\right)$; upper threshold $\left(x_{\text {nop }}^{b}\right)$; upper critical $\left(x_{k p}^{\beta}\right)$ (Figure 1).

The most accessible among a number of methods for determining thresholds is the method of "t-criterion" (Paniotto, 2004), which means constructing a probability density function for a given sample and calculating statistical characteristics: mathematical expectation, standard deviation and asymmetry coefficient. From all variety of types of probability density function for all indicators it is possible to allocate types with the characteristic law of distribution: a) normal, b) lognormal and c) exponential for which formulas to calculate a vector of threshold values are defined (Table 1) (Kharazishvili, 2019; 2021a; 2021b) with clarifications of the distribution: tail to the right, tail to the left (Sukhodolya et al., 2020). 


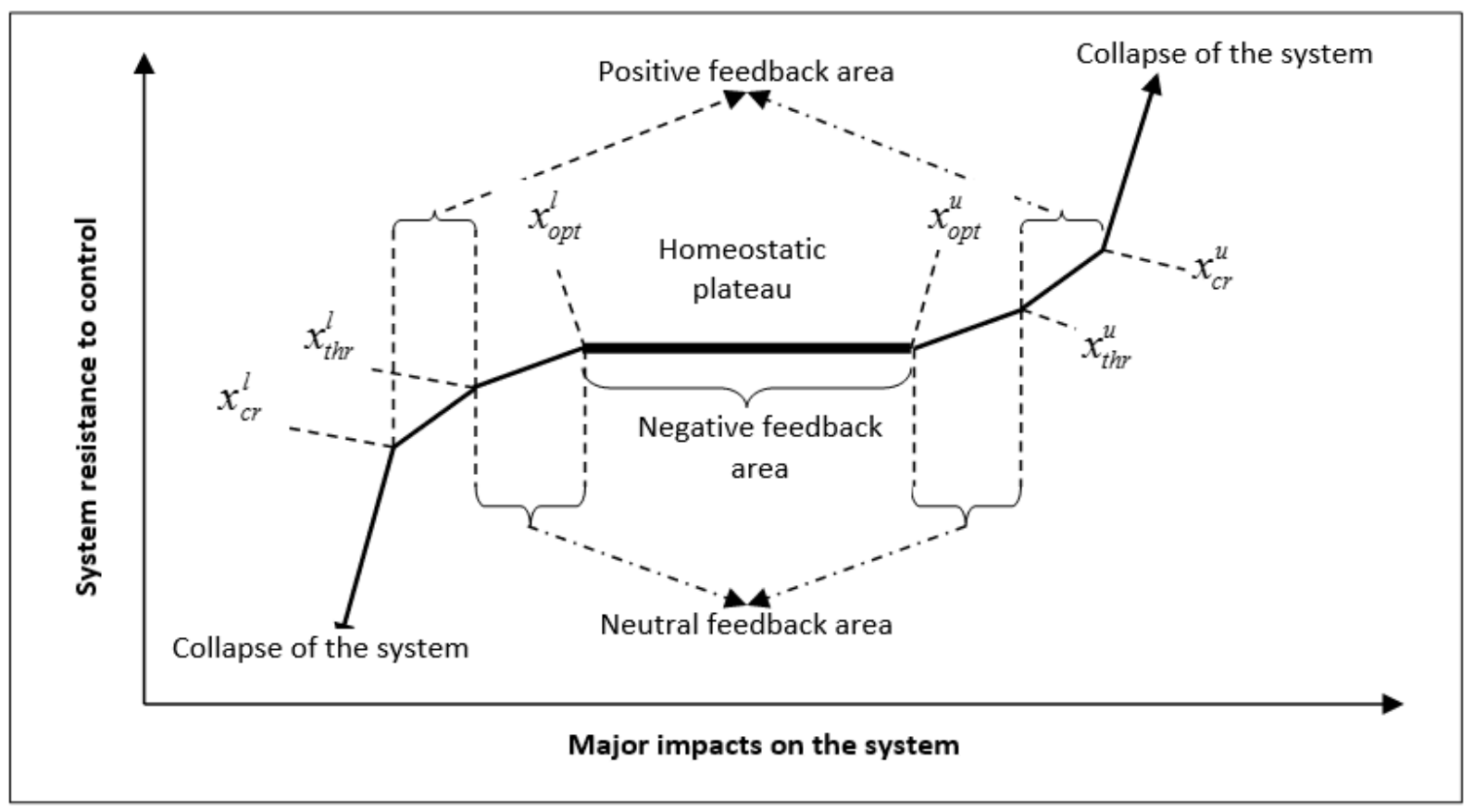

Figure 1. "Homeostatic Plateau" of the Dynamic System

Source: Kharazishvili (2019).

Table 1. Formalised Threshold Vector Values *

\begin{tabular}{ccccc}
\hline $\begin{array}{c}\text { Type of Indicator Probability } \\
\text { Density Function }\end{array}$ & Lower Threshold & $\begin{array}{c}\text { Lower Optimal } \\
\text { Value }\end{array}$ & $\begin{array}{c}\text { Upper Optimal } \\
\text { Value }\end{array}$ & Upper Threshold \\
\hline Normal & $\mu-t \times \sigma$ & $\mu-\sigma$ & $\mu+\sigma$ & $\mu+t \times \sigma$ \\
\hline $\begin{array}{c}\text { Lognormal } \\
\text { (tail to the right) }\end{array}$ & $\mu-t \times \sigma / k_{a s}$ & $\mu-\sigma / k_{a s}$ & $\mu+\sigma$ & $\mu+t \times \sigma$ \\
$\begin{array}{c}\text { Lognormal } \\
\text { (tail to the left) }\end{array}$ & $\mu-t \times \sigma$ & $\mu-\sigma$ & $\mu+\sigma / k_{a s}$ & $\mu+t \times \sigma / k_{a s}$ \\
\hline $\begin{array}{c}\text { Exponential } \\
\text { (tail to the right) } \\
\text { Exponential } \\
\text { (tail to the left) }\end{array}$ & $\mu-\sigma / k_{a s}$ & $\mu$ & $\mu+\sigma$ & $\mu+t \times \sigma$ \\
\hline
\end{tabular}

Note: * For critical values, instead of $t$ we use _3_ or more for short samples.

Source: own elaboration.

Identification of the level of research, education and innovation spaces of European integration consists in a step-by-step integrated convolution of indicators and their threshold values according to the modern universal methodology of integrated assessment (Kharazishvili, 2019; Kharazishvili et al., 2020; Kharazishvili et al., 2019):

the form of the integral index is multiplicative (1):

$$
I_{t}=\prod_{i=1}^{n} z_{i, t}^{a_{i}} ; \quad \sum a_{i}=1 ; \quad a_{i} \geq 0,
$$


where $I$ is an integral index;

$z$ is a normalized indicator;

$a$ is a weighting factor.

The method of normalization is combined (2):

$$
S: z_{i}=\frac{x_{i}}{k_{n o r m, t}}, \quad D: z_{i}=\frac{k_{n o r m, t}-x_{i}}{k_{n o r m, t}}, \quad k_{n o r m, t} \geq x_{\max , t},
$$

where $\quad x_{i}$ is an indicator value;

$S$ is a stimulator; $D$ is a de-stimulator;

$k_{\text {норм,t }}$ is a norming coefficient: for stimulators it is equal to the maximum value from the sample of indicators and threshold values; for de-stimulators it exceeds the maximum values from the sample of indicators and threshold values by $5-10 \%$.

Weighting factors are dynamic: based on the application of the method of "Main components" (3) and the method of "Sliding matrix":

$$
C_{i} \times D_{i}=\left(\begin{array}{l}
d_{1} c_{11}+d_{2} c_{12}+\ldots+d_{j} c_{1 j} \\
d_{1} c_{21}+d_{2} c_{22}+\ldots+d_{j} c_{2 j} \\
\ldots \ldots \ldots \ldots \ldots \ldots \ldots \ldots \ldots \ldots \ldots \\
d_{1} c_{j 1}+d_{2} c_{j 2}+\ldots+d_{j} c_{j j}
\end{array}\right)=\left(\begin{array}{l}
w_{1} \\
w_{2} \\
\ldots \\
w_{j}
\end{array}\right), \quad a_{i}=\frac{w_{i}}{\sum w_{i}},
$$

where $C$ is a matrix of absolute values of factor loads;

$D$ is a vector-matrix of dispersions;

$a$ are weighting coefficients.

Determining the list and significance of the threats impact is carried out according to two criteria:

- by the remoteness from the point of sustainable development - the average value of the homeostatic plateau or the criterion of sustainable development (the list and importance of threats are determined); It is the simultaneous norming and integral convolution of indicators and their threshold values that makes it possible to compare on one scale the deviations of integrated indices from the relevant criteria of sustainable development.

- by the severity of the impact through calculating the coefficients of elasticity (4) (the degree of threats' impact is determined). The elasticity coefficients of each component and indicators explain the degree of influence of individual components and indicators on the level of the integrated index (by how many percent the output value will change when changing $1 \%$ of the input value) and are the necessary information to develop priority influence measures:

$$
E=\frac{\Delta y}{\Delta x} \cdot \frac{x}{y}
$$


The rate of STP is determined by the "Solow residue" method for the Cobb - Douglas production function (5) (Kharazishvili, 2018; 2021a; 2021b) by logarithmizing and obtaining logarithmic derivatives and determining the contribution of STP In the following formulas, to simplify them, the symbol of time $t$ is omitted, but is implied (6).

$$
V_{t}^{S}\left(P_{t}\right)=e^{\gamma t} L_{t}^{a_{t}} K_{z, t}^{1-a_{t}}=e^{\gamma t}\left[\xi_{t} N_{t}\left(P_{t}\right) \frac{W_{t}}{P_{t}} k_{s n}\right]^{a_{t}}\left(\vartheta_{t} K_{t}\right)^{1-a_{t}}
$$

where $V_{t}^{S}$ is the actual issue of aggregate supply;

$e^{\gamma t}$ is the scientific and technological progress (STP);

$\gamma$ is the STP rate;

$L$ is labour costs;

$\xi_{t}=N_{e f, t} / N_{z a g, t}$ is the share of the effective number of taxpayers in total employment;

$N_{e f, t}$ is the effective number of taxpayers (employees plus another category of workers, reduced to the equivalent of employees for all taxes and wages);

$N_{z a g, t}$ is general employment;

$N_{t}\left(P_{t}\right)$ is the function of optimal demand for labour, determined from the condition of equality of the labour marginal product value to the nominal wage rate;

$W_{t}$ is the average annual nominal wages of employees;

$k_{s n, t}$ is the coefficient of social loads;

$\vartheta_{t}$ is the capital utilization ratio;

$K_{t}$ is capital expenditures;

$\alpha_{t}$ is the coefficient of elasticity at labour costs;

$1-\alpha_{t}$ is the coefficient of elasticity at cost of capital;

$P_{t}$ is GDP deflator; $t$ is the period of time.

$$
\begin{aligned}
& \text { Tempo_NTP }=\frac{\dot{V}}{V}-\dot{a}\left(\ln \xi+\ln 0,001 N+\ln W 12-\ln P+\ln k_{s n}\right)- \\
& -a\left(\frac{\dot{\xi}}{\xi}+\frac{\dot{N}}{N}+\frac{\dot{W}}{W}-\frac{\dot{P}}{P}\right)+\dot{a}(\ln \vartheta+\ln K)-(1-a)\left(\frac{\dot{\vartheta}}{\vartheta}+\frac{\dot{K}}{K}\right),
\end{aligned}
$$

where $\frac{\dot{V}}{V}, \frac{\dot{\xi}}{\xi}, \frac{\dot{N}}{N}, \frac{\dot{W}}{W}, \frac{\dot{\vartheta}}{\vartheta}, \frac{\dot{K}}{K}, \frac{\dot{P}}{P}$ are rates of the corresponding variables;

$\dot{a}$ is a derivative of the coefficient of elasticity ( $\mathrm{N}$ is set in million people, $\mathrm{W}$ in UAH per month).

The transition from output to GDP (GRP) is carried out through the coefficient of manufacturability (), which in each period is determined by the ratio of GDP (GRP) to output 
according to macroeconomic identity (7) "output is equal to the sum of intermediate consumption and GDP":

$$
G D P(P)=\sigma V^{S}(P)
$$

Scientific substantiation of strategic scenarios of the European integration of research, education and innovation spaces of Ukraine and Poland. Most of the economically developed countries of the world, given the instability of economies' operation, have recognized the need not only to predict the future, but also its active formation by means of such a tool as Foresight. The main purpose of Foresighting is to determine the possible future, create the desired image of the future and determine strategies for achieving it. Forecasting, technology prospects estimates, research of the future and other forms of Foresight (SWOT analysis, expert estimates, trends' extrapolation, brainstorming) are an attempt to identify long-term trends and, based on them, to coordinate decision-making.

Unfortunately, expert estimates are full of subjectivity and do not exclude fundamental errors; forecasting trends using the principle of classical forecasting "the past determines the future" in the face of rapid change is inappropriate. For example, attempts to predict the integral indices' dynamics using polynomials or regression equations indicate incapability and generally discredit economic and mathematical modelling.

With this in mind, a strategic planning approach is proposed, which uses the principle "the future is determined by the trajectory into the future" (Kharazishvili, 2019), which consists of the following stages:

- identifying the current state through integrated assessment;

- goal setting for the desired perspective;

- constructing the desired trajectories according to development scenarios;

- sequential decomposing integral indices into components and indicators using adaptive control methods from the management theory (Figure 2);

- de-norming indicators: the implementation of the inverse norming procedure, i.e., the transition from dimensionless values to macro indicators in natural units of measurement according to norming formulas.

Strategic planning is to result in obtaining, in the dynamics per each year, the necessary values of indicators and relevant macro indicators, compliance with which will provide the desired trajectory of sustainable development. 
Vector of anticipated values of safety components (indicators)

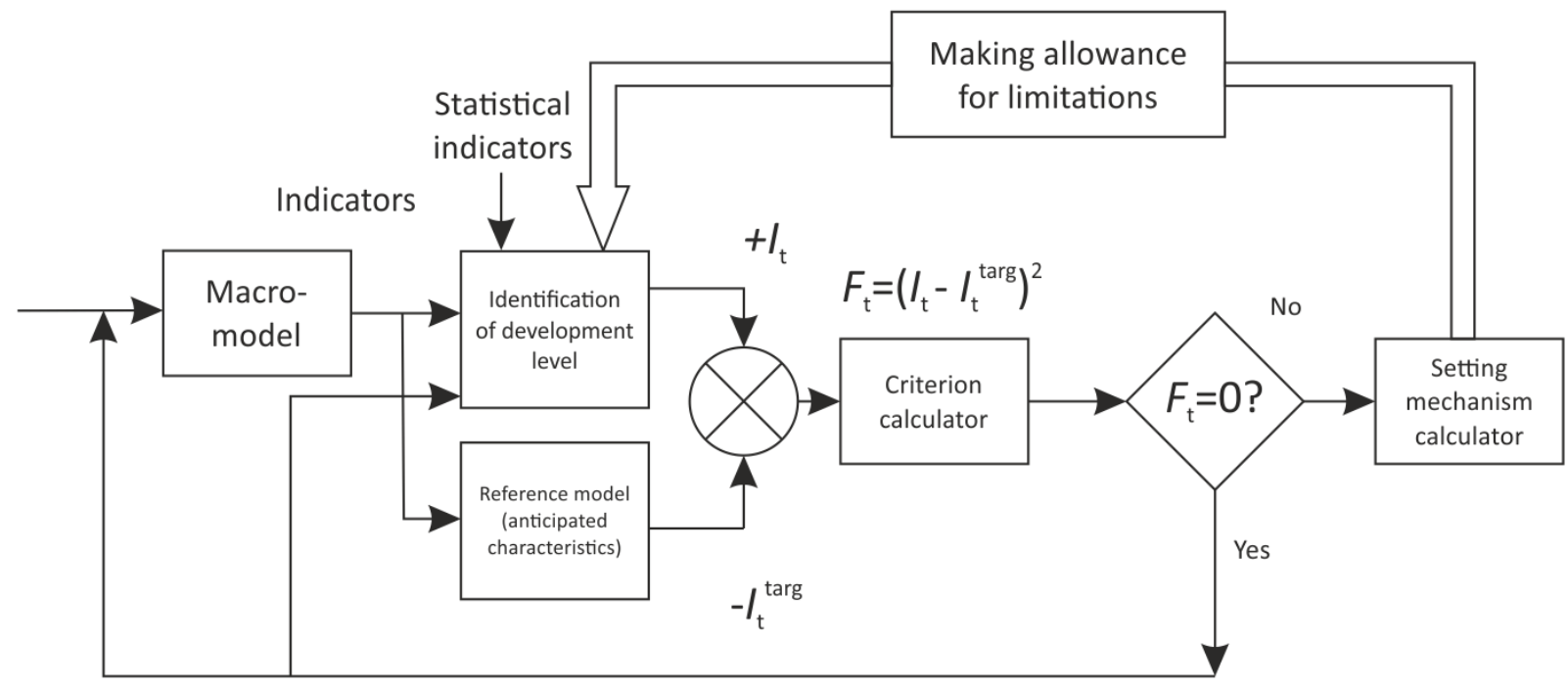

Figure 2. Generalized Scheme of Adaptive Control System with a Reference Model Source: Kharazishvili (2019).

\section{Results}

The stage involves the development of the structure (Figure 3) and detailing of the components and their indicators, the formation of the indicators dynamics and their affiliation to stimulators (S) or de-stimulators (D) (Table 2).

Table 2. Components and indicators of subsystems of research, education and innovative spaces of European integration

\begin{tabular}{|c|c|}
\hline Education (resource provision) & Science and innovation (resources and outcomes) \\
\hline $\begin{array}{l}\text { 1. The level of higher education coverage, per } 10 \\
\text { thousand population; (S) } \\
\text { 2. The level of secondary education coverage, per } \\
10 \text { thousand population; (S) } \\
\text { 3. The level of state funding of education, \% of } \\
\text { output; (S) } \\
\text { 4. The level of state funding of higher education, \% } \\
\text { of output; (S) } \\
\text { 5. Average costs per } 1 \text { pupil (student), thousand } \\
\text { dollars US for PPP; (S) } \\
\text { 6. The level of capital investment in education, \% of } \\
\text { total expenditure on education; (S) } \\
\text { 7. The level of labour remuneration in education of } \\
\text { output; (S) }\end{array}$ & $\begin{array}{l}\text { 1. The pace of scientific and technological progress (S) } \\
\text { 2. The level of scientific research funding, \% of GDP (S) } \\
\text { 3. The level of funding for innovation, \% of GDP, (S) } \\
\text { 4. The level of innovation activity of enterprises, \% of } \\
\text { the total number (S) } \\
\text { 5. The level of sales of innovative products, \% of total } \\
\text { sales (S) } \\
\text { 6. The level of scientific research costs per person, USD } \\
\text { US for PPP (S) } \\
\text { 7. The level of invention activity (patents and utility } \\
\text { models), per } 1 \text { million population (S) }\end{array}$ \\
\hline
\end{tabular}

Source: own elaboration. 


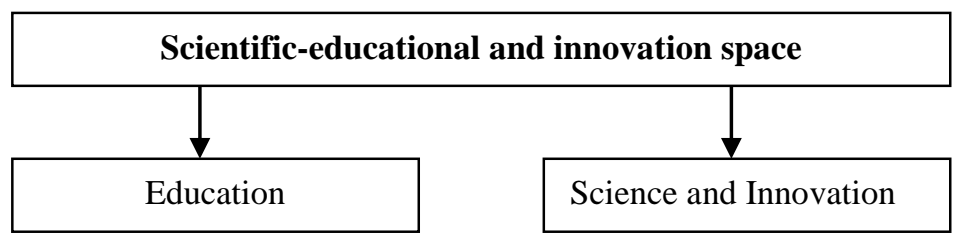

Figure 3. The structure of research, education and innovation spaces of European integration Source: own elaboration.

The dynamics of indicators of research, education and innovation spaces in Ukraine and Poland was determined according to the official data of the State Statistics Service of Ukraine and Poland. To calculate the vector of threshold values (Table 3), a sample of values of similar indicators from EU countries was used for international comparison of statistical services of Ukraine and Poland, as well as Eurostat data. The given list of indicators is not a dogma, it depends on the depth and objectives of the study, it should be consistent for all comparable countries and, finally, reflects the vision of the authors.

The identification of the level of research, education and innovation spaces consists in applying the proposed methodology of integrated evaluation and simultaneous integrated convolution both for indicators $(I)$ and for their threshold values $(P)$, which is reflected in the multifactor hierarchical model (4).

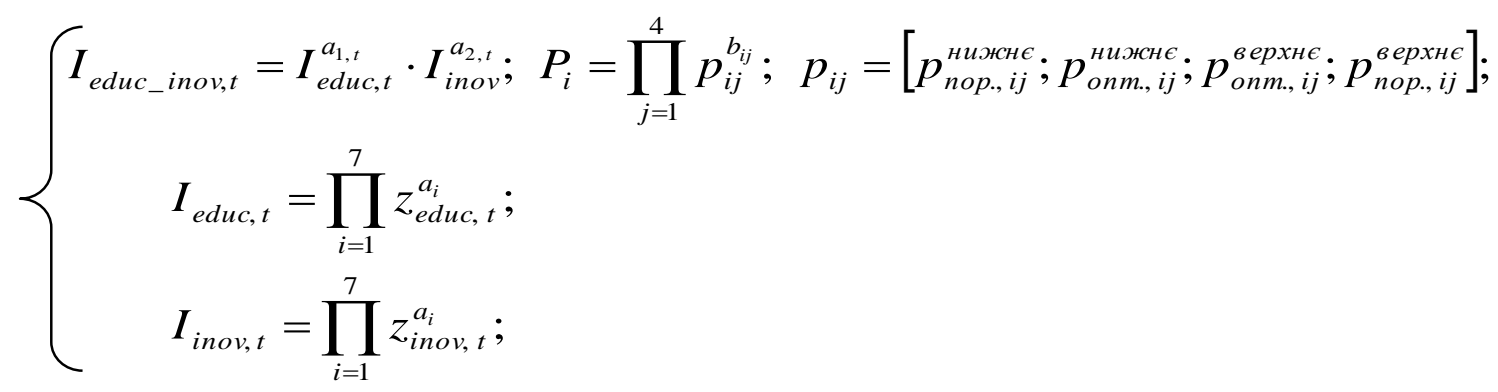

Modelling the integrated indices dynamics of the components of the level of research, education and innovation spaces of Ukraine and Poland in comparison with the integrated threshold values, i.e., in the security dimension, gives the following picture of the current state (Figure 4) and in general (Figure 5). 
Table 3. Vectors of Threshold Values of Indicators of Research, Education and Innovation Spaces of European Integration

\begin{tabular}{|c|c|c|c|c|c|c|}
\hline Components and Indicators & $\begin{array}{l}\text { Lower } \\
\text { threshold }\end{array}$ & $\begin{array}{c}\text { Lower } \\
\text { Optimal } \\
\text { Value }\end{array}$ & $\begin{array}{c}\text { Upper } \\
\text { Optimal } \\
\text { Value }\end{array}$ & $\begin{array}{l}\text { Upper } \\
\text { threshold }\end{array}$ & $\begin{array}{l}\text { Ukraine } \\
2019\end{array}$ & $\begin{array}{c}\text { Poland } \\
2019\end{array}$ \\
\hline \multicolumn{7}{|l|}{ Education } \\
\hline $\begin{array}{l}\text { - The level of higher education coverage, per } 10 \\
\text { thousand population; }\end{array}$ & 220 & 300 & 450 & 600 & 344 & 313,7 \\
\hline $\begin{array}{l}\text { - The level of secondary education coverage, per } \\
10 \text { thousand population; }\end{array}$ & 1050 & 1345 & 1650 & 2300 & 910 & 798 \\
\hline $\begin{array}{l}\text { - The level of state funding of education, } \% \text { of } \\
\text { output; }\end{array}$ & 2.5 & 2.8 & 3.9 & 6.0 & 2.24 & 1.87 \\
\hline $\begin{array}{l}\text { - The level of public funding for higher education, } \\
\% \text { of output; }\end{array}$ & 0.65 & 0.71 & 1.0 & 1.55 & 0.462 & 0.358 \\
\hline $\begin{array}{l}\text { - Average costs per } 1 \text { pupil (student), thousand } \\
\text { dollars US for PPP; }\end{array}$ & 6.8 & 9.7 & 12.5 & 18.0 & 2.65 & 5.33 \\
\hline $\begin{array}{l}\text { - The level of capital investment in education, \% } \\
\text { of total expenditures on education; }\end{array}$ & 6.5 & 8.9 & 11 & 15 & 2.387 & 9.729 \\
\hline $\begin{array}{l}\text { - The level of labour remuneration in education } \\
\text { of output; }\end{array}$ & 0.2 & 0.26 & 0.32 & 0.382 & 0.1754 & 0.233 \\
\hline \multicolumn{7}{|l|}{ Science and innovation } \\
\hline $\begin{array}{l}\text { - The pace of scientific and technological } \\
\text { progress }\end{array}$ & 0.2 & 0.5 & 2.0 & 5.0 & -2.355 & -0.356 \\
\hline $\begin{array}{l}\text { - The level of scientific research funding, \% of } \\
\text { GDP }\end{array}$ & 1.0 & 2.0 & 4.0 & 5.0 & 0.505 & 1.324 \\
\hline - The level of funding for innovation, $\%$ of GDP, & 0.5 & 1.5 & 2.5 & 3.5 & 0.354 & 0.941 \\
\hline $\begin{array}{l}\text { - The level of innovation activity of enterprises, } \\
\% \text { of the total number }\end{array}$ & 25 & 45 & 60 & 80 & 15 & 21.7 \\
\hline $\begin{array}{l}\text { - The level of sales of innovative products, } \% \text { of } \\
\text { total sales }\end{array}$ & 10 & 15 & 30 & 40 & 1.0 & 9.3 \\
\hline $\begin{array}{l}\text { - The level of scientific research costs per } \\
\text { person, USD for PPP) }\end{array}$ & 345 & 430 & 900 & 1100 & 36.9 & 207.7 \\
\hline $\begin{array}{l}\text { - The level of invention activity (patents and } \\
\text { utility models), per } 1 \text { million population }\end{array}$ & 110 & 137 & 205 & 245 & 224.3 & 92.49 \\
\hline
\end{tabular}

Source: calculated by the authors.
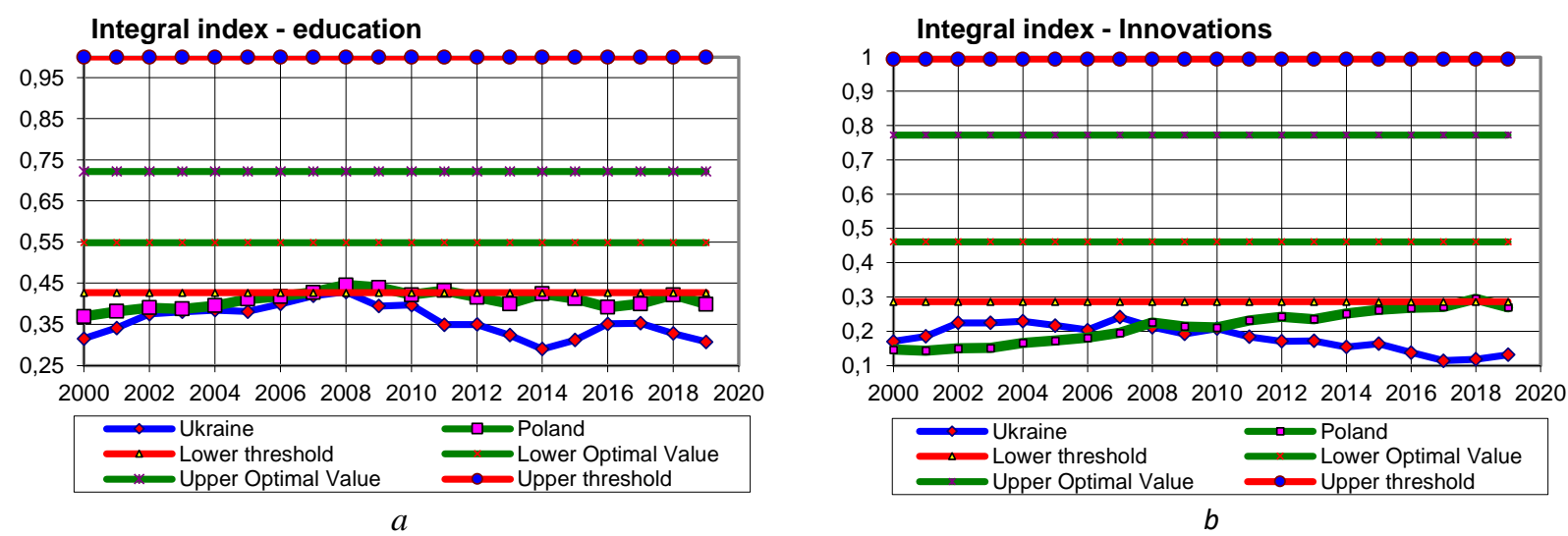

Figure 4. Dynamics of integrated indices of research, education (a) and innovation spaces (b) of Ukraine and Poland.

Source: own elaboration. 


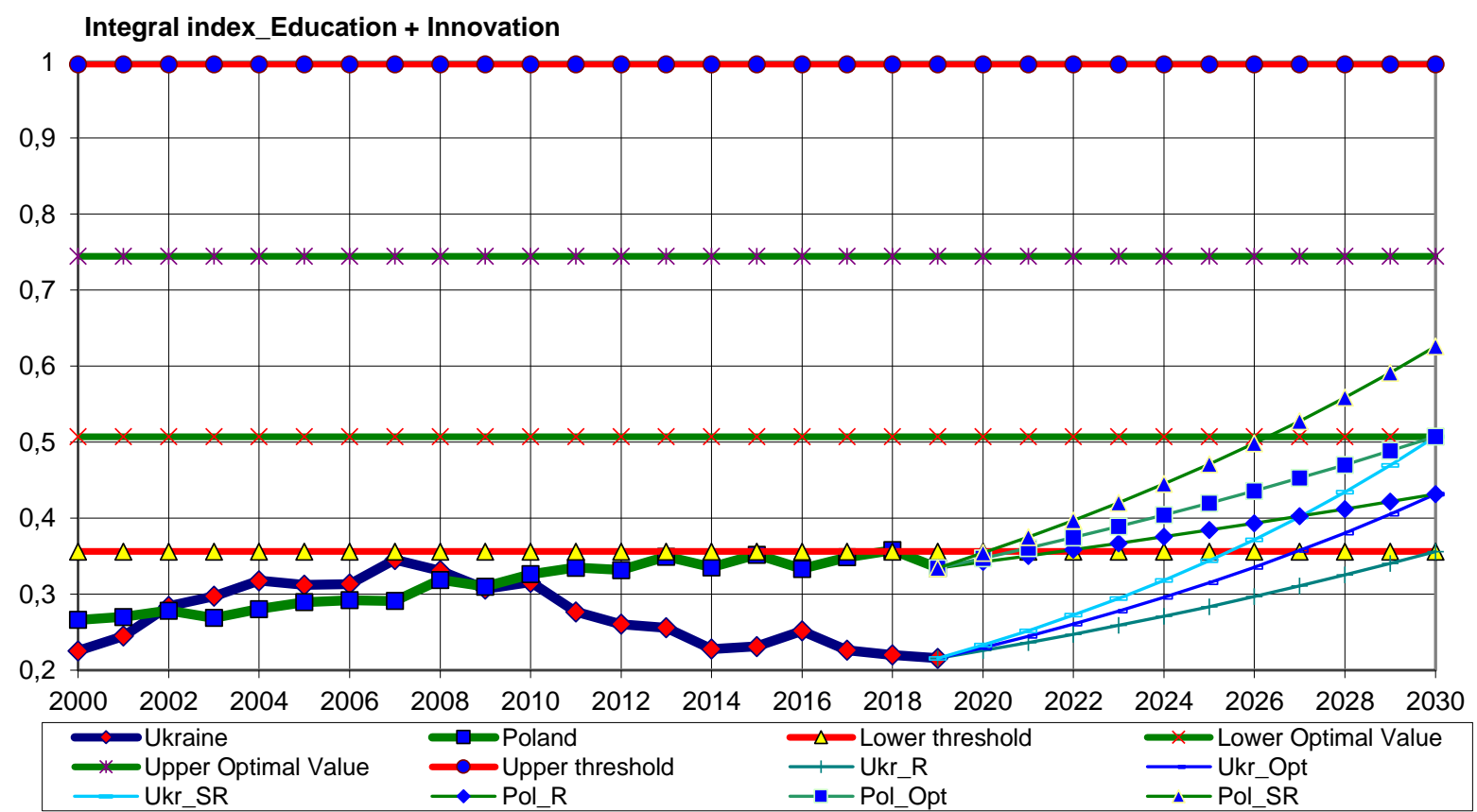

Figure 5. Dynamics of integrated indices of educational and innovation space of Ukraine and Poland with strategic goals and development scenarios until 2030

Source: own elaboration.

Thus, according to the results of calculations, Ukraine is in the crisis (orange) zone - below the lower threshold, Poland is on the border of the crisis-pre-crisis (orange-red) zone. It is the comparison of the dynamics of integrated indices with integrated thresholds on one scale that makes it possible to identify the current situation and carry out strategic planning for the medium-term perspective - three strategic scenarios for Poland (realistic, optimistic, sustainable development) and three for Ukraine: (realistic, optimistic, entry to the sustainable development zone). The scientific substantiation of the vector of threshold values and their integral convolution makes it possible to determine the gradations of the countries' distribution by level of innovative development: critical (red) level (below the lower critical threshold), crisis (orange) level (between the lower critical and lower threshold), pre-crisis (yellow) level (between lower optimal and lower threshold) optimal (green) level (between lower optimal and upper optimal), instead of subjective setting of artificial ranges distribution.

Determining the deviations of integrated indices from the average value of the "homeostatic plateau" - the criterion of sustainable development - demonstrates the imbalances of sustainable development and determines the list and importance of threats (Figure 6). The most important task of the policy is to eliminate imbalances, i.e., to reduce to zero the deviation of each indicator, for example, by the end of 2030. Out of 14 indicators of research, education and innovation space, 12 indicators pose a critical threat to Ukraine and 9 indicators to Poland. 
Therefore, changing dynamics of these indicators from negative to positive to ensure their location in the optimal zone is a priority of the government of each country, which will be an objective indicator of the reforms' effectiveness in any area of security.

Deviation - Ukraine

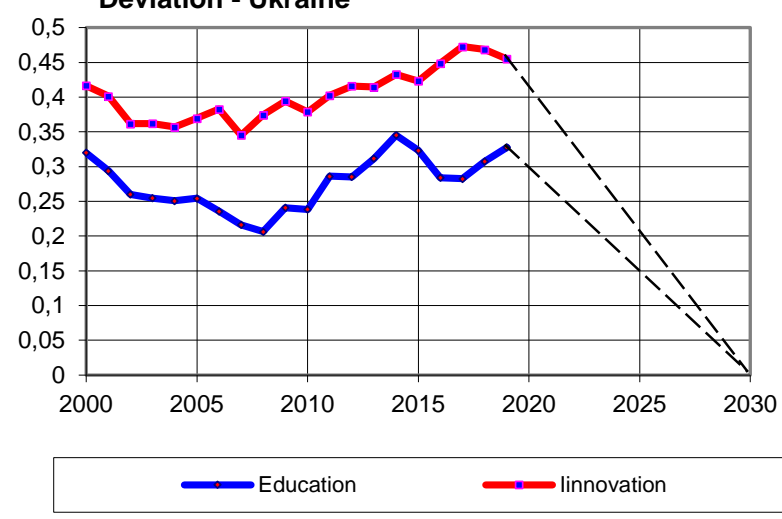

$a$

Imbalances "Education" Ukraine

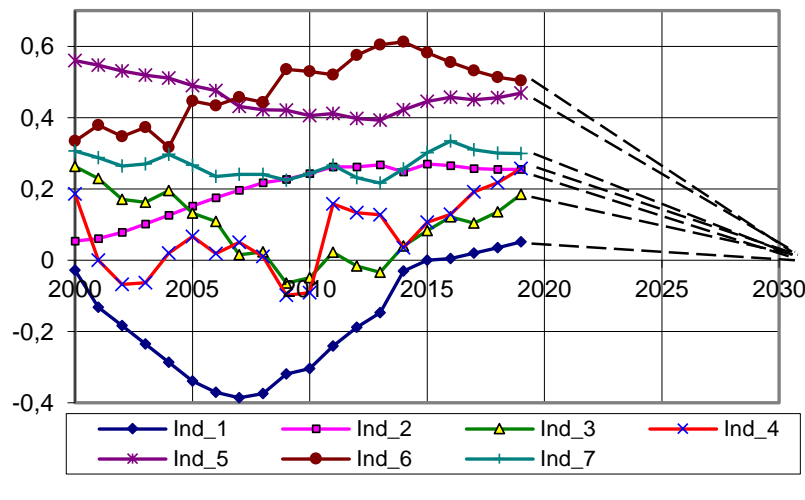

c

Imbalances of "Innovation" Ukraine

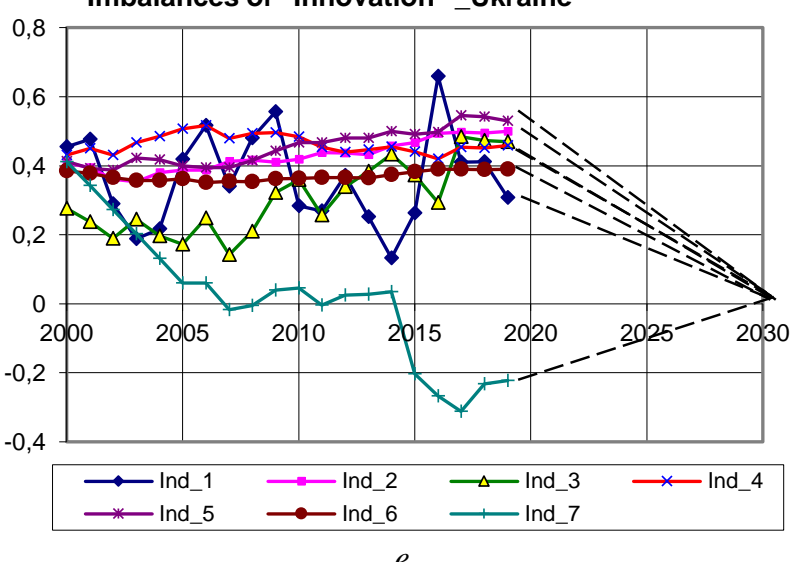

Deviation - Poland

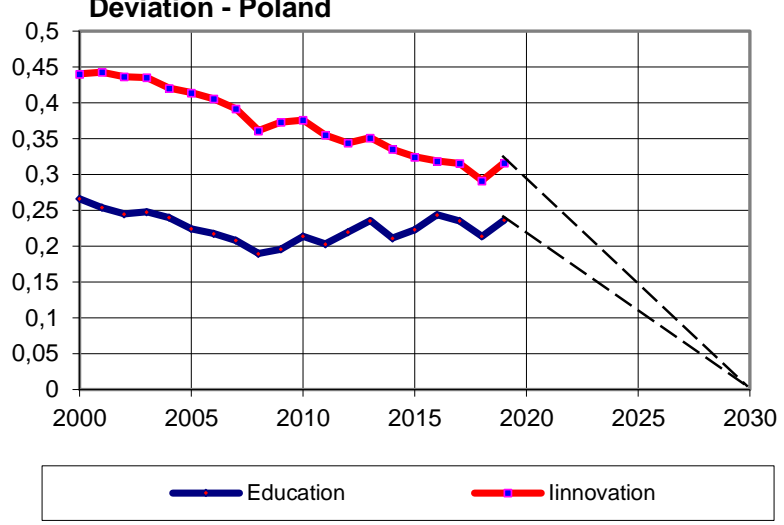

$b$

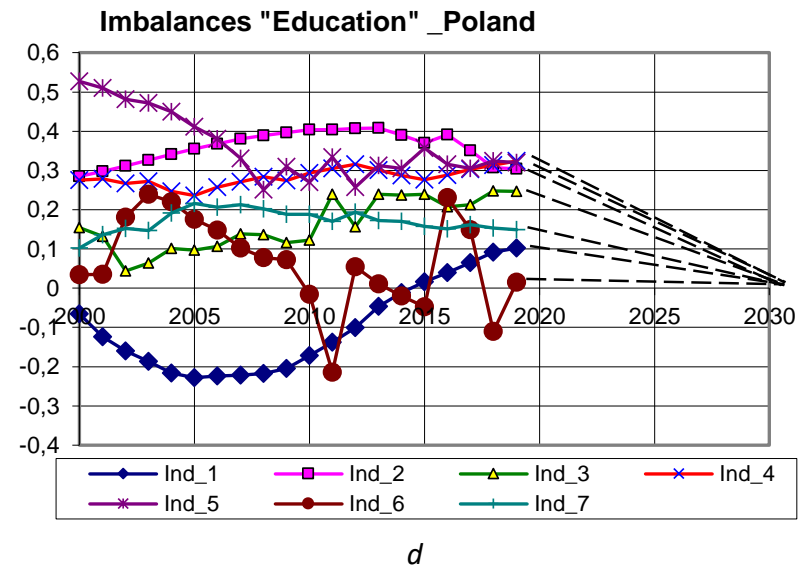

Imbalances "Innovation"_Poland

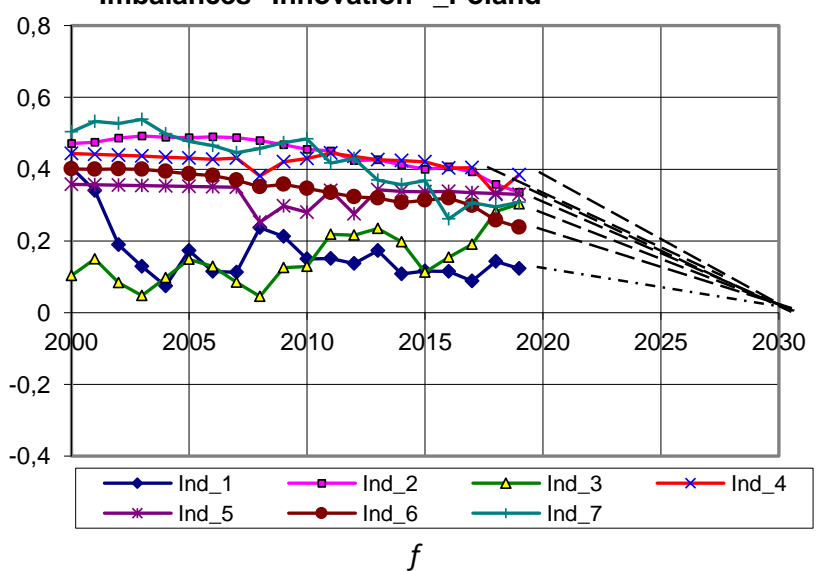

Figure 6. Dynamics of imbalances of research, education and innovative spaces of European integration

Source: own elaboration. 
That is why the importance of the influence of individual components and indicators through calculating elasticity coefficients (4) (Table 4-5) is important for implementing regulatory actions aimed at reducing development imbalances.

Table 4. Critical threats and the importance of their impact on the level of research, education and innovation security of Ukraine

\begin{tabular}{|c|c|c|}
\hline $\begin{array}{l}\text { Components and indicators of research, } \\
\text { education and innovation security - threats by } \\
\text { remoteness from the criterion of sustainable } \\
\text { development (importance of the threat) }\end{array}$ & $\begin{array}{l}\text { Components and indicators of research, } \\
\text { education and innovation security - threats } \\
\text { in terms of the significance of the impact }\end{array}$ & $\begin{array}{l}\text { Coefficient } \\
\text { of elasticity }\end{array}$ \\
\hline \multicolumn{3}{|c|}{ UKRAINE } \\
\hline \multicolumn{3}{|c|}{ By components } \\
\hline 1. Innovation & 1. Education & 0.5812 \\
\hline 2. Education & 2. Innovation & 0.4164 \\
\hline \multicolumn{3}{|c|}{ According to education indicators } \\
\hline $\begin{array}{l}\text { 1. The level of capital investment in } \\
\text { education, \% of total expenditure on } \\
\text { education; }\end{array}$ & $\begin{array}{l}\text { 1. The level of state funding of education, } \% \\
\text { of output; }\end{array}$ & 0.1004 \\
\hline $\begin{array}{l}\text { 2. Average costs per } 1 \text { pupil (student), } \\
\text { thousand US dollars /PPP; }\end{array}$ & $\begin{array}{l}\text { 2. Average costs per } 1 \text { pupil (student), } \\
\text { thousand US dollars /PPP; }\end{array}$ & 0.0998 \\
\hline $\begin{array}{l}\text { 3. The level of labour remuneration in } \\
\text { education of output; }\end{array}$ & $\begin{array}{l}\text { 3. The level of higher education coverage, } \\
\text { per } 10 \text { thousand population; }\end{array}$ & 0.0982 \\
\hline $\begin{array}{l}\text { 4. The level of state funding of higher } \\
\text { education, } \% \text { of output; }\end{array}$ & $\begin{array}{l}\text { 4. The level of labour remuneration in } \\
\text { education of output; }\end{array}$ & 0.0981 \\
\hline $\begin{array}{l}\text { 5. The level of secondary education coverage, } \\
\text { per } 10 \text { thousand population; }\end{array}$ & $\begin{array}{l}\text { 5. The level of capital investment in } \\
\text { education, \% of total expenditure on } \\
\text { education; }\end{array}$ & 0.0825 \\
\hline $\begin{array}{l}\text { 6. The level of state funding of education, } \% \\
\text { of output; }\end{array}$ & $\begin{array}{l}\text { 6. The level of state funding of higher } \\
\text { education, } \% \text { of output; }\end{array}$ & 0.0617 \\
\hline $\begin{array}{l}\text { 7. The level of higher education coverage, per } \\
10 \text { thousand population; }\end{array}$ & $\begin{array}{l}\text { 7. The level of secondary education } \\
\text { coverage, per } 10 \text { thousand population; }\end{array}$ & 0.0391 \\
\hline \multicolumn{3}{|c|}{ According to indicators of innovation } \\
\hline $\begin{array}{l}\text { 1. The level of innovative products' sales, \% of } \\
\text { total sales }\end{array}$ & $\begin{array}{l}\text { 1. The level of innovative products' sales, \% } \\
\text { of total sales }\end{array}$ & 0.0671 \\
\hline $\begin{array}{l}\text { 2. The level of scientific research funding, } \% \\
\text { of GDP }\end{array}$ & $\begin{array}{l}\text { 2. The level of scientific research } \\
\text { expenditures per person, USD for PPP); }\end{array}$ & 0.0662 \\
\hline $\begin{array}{l}\text { 3. The level of financing the innovation } \\
\text { activity, \% of GDP, }\end{array}$ & $\begin{array}{l}\text { 3. The level of inventive activity (patents } \\
\text { and utility models), per } 1 \text { million of } \\
\text { population ; }\end{array}$ & 0.0659 \\
\hline $\begin{array}{l}\text { 4. The level of enterprises' innovation activity, } \\
\% \text { of the total number; }\end{array}$ & $\begin{array}{l}\text { 4. The level of scientific research funding, } \% \\
\text { of GDP }\end{array}$ & 0.0647 \\
\hline $\begin{array}{l}\text { 5. The level of scientific research expenditures } \\
\text { per person, USD for PPP); }\end{array}$ & $\begin{array}{l}\text { 5. The rate of scientific and technological } \\
\text { progress, \%; }\end{array}$ & 0.0592 \\
\hline $\begin{array}{l}\text { 6. The pace of scientific and technological } \\
\text { progress, \%; }\end{array}$ & $\begin{array}{l}\text { 6. The level of financing the innovation } \\
\text { activity, \% of GDP, }\end{array}$ & 0.0545 \\
\hline $\begin{array}{l}\text { 7. The level of inventive activity (patents and } \\
\text { utility models), per } 1 \text { million of population; }\end{array}$ & $\begin{array}{l}\text { 7. The level of innovation activity of } \\
\text { enterprises, } \% \text { of the total number; }\end{array}$ & 0.0379 \\
\hline
\end{tabular}
Source: calculated by the authors. 
Table 5. Critical threats and the importance of their impact on the level of research, education and innovation security of Poland

\begin{tabular}{|c|c|c|}
\hline $\begin{array}{l}\text { Components and indicators of research, } \\
\text { education and innovation security - threats by } \\
\text { remoteness from the criterion of sustainable } \\
\text { development (importance of the threat) }\end{array}$ & $\begin{array}{l}\text { Components and indicators of research, } \\
\text { education and innovation security - threats } \\
\text { in terms of the significance of the impact }\end{array}$ & $\begin{array}{l}\text { Coefficient } \\
\text { of elasticity }\end{array}$ \\
\hline \multicolumn{3}{|l|}{$\begin{array}{ll}\text { POLAND } \\
\end{array}$} \\
\hline \multicolumn{3}{|c|}{ By components } \\
\hline 1. Innovation & 1. Education & 0.5448 \\
\hline 2. Education & 2. Innovation & 0.4527 \\
\hline \multicolumn{3}{|c|}{ According to education indicators } \\
\hline $\begin{array}{l}\text { 1. The level of state funding of higher } \\
\text { education, } \% \text { of output; }\end{array}$ & $\begin{array}{l}\text { 1. The level of secondary education } \\
\text { coverage, per } 10 \text { thousand population; }\end{array}$ & 0.0961 \\
\hline $\begin{array}{l}\text { 2. Average costs per } 1 \text { pupil (student), } \\
\text { thousand US dollars /PPP; }\end{array}$ & $\begin{array}{l}\text { 2. The level of higher education coverage, } \\
\text { per } 10 \text { thousand population; }\end{array}$ & 0.0942 \\
\hline $\begin{array}{l}\text { 3. The level of secondary education coverage, } \\
\text { per } 10 \text { thousand population; }\end{array}$ & $\begin{array}{l}\text { 3. The level of labour remuneration in } \\
\text { education of output; }\end{array}$ & 0.0934 \\
\hline $\begin{array}{l}\text { 4. The level of state funding of education, \% } \\
\text { of output; }\end{array}$ & $\begin{array}{l}\text { 4. Average costs per } 1 \text { pupil (student), } \\
\text { thousand US dollars /PPP; }\end{array}$ & 0.0934 \\
\hline $\begin{array}{l}\text { 5. The level of labour remuneration in } \\
\text { education of output; }\end{array}$ & $\begin{array}{l}\text { 5. The level of state funding of education, } \% \\
\text { of output; }\end{array}$ & 0.0867 \\
\hline $\begin{array}{l}\text { 6. The level of higher education coverage, per } \\
10 \text { thousand population; }\end{array}$ & $\begin{array}{l}\text { 6. The level of capital investment in } \\
\text { education, \% of total expenditure on } \\
\text { education; }\end{array}$ & 0.0400 \\
\hline $\begin{array}{l}\text { 7. The level of capital investment in } \\
\text { education, } \% \text { of total expenditure on } \\
\text { education }\end{array}$ & $\begin{array}{l}\text { 7. The level of state funding of higher } \\
\text { education, } \% \text { of output; }\end{array}$ & 0.0396 \\
\hline \multicolumn{3}{|c|}{ According to indicators of innovation } \\
\hline $\begin{array}{l}\text { 1. The level of enterprises' innovation activity, } \\
\% \text { of the total number; }\end{array}$ & $\begin{array}{l}\text { 1. The level of scientific research funding, \% } \\
\text { of GDP }\end{array}$ & 0.0823 \\
\hline $\begin{array}{l}\text { 2. The level of scientific research funding, \% } \\
\text { of GDP }\end{array}$ & $\begin{array}{l}\text { 2. The level of scientific research } \\
\text { expenditures per person, USD for PPP); }\end{array}$ & 0.0807 \\
\hline $\begin{array}{l}\text { 3. The level of innovative products' sales, \% of } \\
\text { total sales; }\end{array}$ & $\begin{array}{l}\text { 3. The level of financing the innovation } \\
\text { activity, \% of GDP, }\end{array}$ & 0.0766 \\
\hline $\begin{array}{l}\text { 4. The level of inventive activity (patents and } \\
\text { utility models), per } 1 \text { million of population; }\end{array}$ & $\begin{array}{l}\text { 4. The level of innovation activity of } \\
\text { enterprises, } \% \text { of the total number; }\end{array}$ & 0.0741 \\
\hline $\begin{array}{l}\text { 5. The level of financing the innovation } \\
\text { activity, \% of GDP, }\end{array}$ & $\begin{array}{l}\text { 5. The level of inventive activity (patents } \\
\text { and utility models), per } 1 \text { million of } \\
\text { population; }\end{array}$ & 0.0668 \\
\hline $\begin{array}{l}\text { 6. The level of scientific research expenditures } \\
\text { per person, USD for PPP); }\end{array}$ & $\begin{array}{l}\text { 6. The level of innovative products' sales, \% } \\
\text { of total sales }\end{array}$ & 0.0481 \\
\hline $\begin{array}{l}\text { 7. The pace of scientific and technological } \\
\text { progress, \%; }\end{array}$ & $\begin{array}{l}\text { 7. The rate of scientific and technological } \\
\text { progress, \%; }\end{array}$ & 0.0232 \\
\hline
\end{tabular}
Source: calculated by the authors.

The results of the calculations show the fact that each country has its own "bottlenecks" in research, educational and innovative development. In terms of the components of "education" and "innovation", the component "innovation" most lags behind the level of the developed EU countries in Poland and in Ukraine, while "education" prevails in terms of the 
importance of the impact. And this is quite logical, as the innovative capacity of scientists depends on the quality of education. If, according to the integrated education index, Poland balances at the level of the lower threshold value (Figure 4, a), Ukraine has a negative dynamic in the critical zone - below the lower threshold value. According to the integrated index of innovation after 2007, Poland has a positive dynamics of approaching from the critical to the crisis zone, and Ukraine has a negative one in the critical zone.

As for education indicators, the three most important critical threats to educational security in Ukraine are "the level of capital investment in education, $\%$ of total education expenditures," "the average cost per student, in thousand US dollars for PPP" and "the level of remuneration in education of output." The expected consequence of contempt for the financing of education in Ukraine is the critical level of almost all indicators of innovation. Another consequence of the current situation is the rejuvenation of the contingent of people with a doctorate degree with a simultaneous significant reduction in their scientific level.

The situation in Poland is somewhat better: the indicators "level of state funding of higher education,\% of output", "the average costs per 1 pupil (student), thousand US dollars per PPP" and "the level of secondary education coverage per 10 thousand population" need improving, which determines the critical level of the following three indicators of innovation: "the level of innovative activity of enterprises,\% of total", "the level of scientific research funding,\% of GDP", "the level of innovative products' sales, \% of the total sales".

Comparing the dynamics of integrated indices with integrated thresholds on the same scale allows setting strategic goals and building a trajectory of their achievement in a given perspective, i.e., implementing the principle "the future is determined by the trajectory into the future" (Figure 5). The most likely scenarios can be identified as follows:

for Poland:

1. Realistic: reaching the average level between the lower threshold and the lower optimal values.

2. Optimistic: reaching the level of the lower optimal value (entering the optimal zone of the EU).

3. Scenario of balanced sustainable development: reaching the level of average optimal value (homeostatic plateau) - the criterion of sustainable development.

for Ukraine:

1. Realistic: reaching the level of the lower threshold.

2. Optimistic: reaching the average level between the lower threshold and the lower optimal values;

3. Sustainable development: reaching the level of the lower optimal value (entering the optimal zone of the EU countries).

Strategic planning to achieve the target level of research, education and innovation security is carried out taking into account the trajectory of transferring the system from the current level 
to the target one (Figure 5). Knowing strategic goals and desired values of the integrated index per each year determines the solution of the problem of decomposition of integrated indices, i.e., the synthesis of their necessary values using adaptive control methods from the management theory (Leondes, 1965; Aoki, 1965). To do this task, there is used the standard procedure of strategizing "Strategy" in the C ++ programming language, developed by the author of the proposed method (Kharazishvili, 2019), which implements an adaptive method of regulation with a short feedback cycle (without a macro model). The long feedback mode is used for more serious research.

The reference to the standard procedure "STRATEGY" is carried out as follows:

$$
F_{\text {min }}=\operatorname{strategy}\left(P, f, n_{1}, n_{2}, x, f_{\text {zad }}, p_{\max }, p_{\text {min }}, \text { eps, func }\right)
$$

where $F_{\min }$ is the resulting error of the solution;

$P$ is the vector of normalized indicators of the integrated index, from which the strategizing begins - the original vector of the desired values of the indicators corresponding to the specified value of the integrated index);

$f$ is the initial value of the integral index;

$n_{1}$ is the initial number of the indicator;

$n_{2}$ is the end number of the indicator;

$f_{\text {zad }}$ is the set value of the integral index;

$p_{\max }$ is the vector of normalized maximum values of adjusted indicators;

$p_{\min }$ is the vector of normalized minimum values of adjusted indicators;

eps is a set error of the solution;

func is the function pointer that is called for computing the optimization criterion.

The initial vector of normalized indicators, the initial vector of normalized required values of indicators, as well as the initial vector of required values of indicators in natural (physical) measurement units through the use of the inverse normalization procedure are used for further calculations of macro indicators per each year of the future trajectory. The calculations give the following dynamics of the strategic values of the components and their indicators according to certain development scenarios (Table 6).

It is obvious that the calculated strategic values of indicators (these are relative values), which are determined by the ratio of macro indicators, can be obtained by many of their values, so it is necessary to link to the strategic values of some important macro indicator against which all other macro indicators can be calculated. Such a macro indicator can be "GDP per capita" at the current exchange rate "(Kharazishvili Y., Lyashenko V., 2019, p. 296). 
Table 6. Evaluation of components' and indicators' strategic values of research, education and innovation spaces of the European integration at the end of 2030

\begin{tabular}{|c|c|c|c|}
\hline Indicators & Scenario 1 & Scenario 2 & Scenario 3 \\
\hline \multicolumn{4}{|l|}{ UKRAINE } \\
\hline research, education and innovation spaces & 0.3561 & 0.4316 & 0.5071 \\
\hline Education & 0.3616 & 0.4504 & 0.5464 \\
\hline $\begin{array}{l}\text { - the level of higher education coverage, per } 10 \text { thousand } \\
\text { population; }\end{array}$ & 357.52 & 387.93 & 428.38 \\
\hline $\begin{array}{l}\text { - the level of secondary education coverage, per } 10 \text { thousand } \\
\text { population; }\end{array}$ & 940.2 & 1008.1 & 1099.2 \\
\hline - the level of state funding of education, $\%$ of output; & 2.447 & 2.891 & 3.444 \\
\hline - the level of state funding of higher education, \% of output; & 0.5035 & 0.5922 & 0.7031 \\
\hline - average costs per 1 pupil (student), thousand dollars US for PPP; & 4.0346 & 6.356 & 8.793 \\
\hline $\begin{array}{l}\text { - the level of capital investment in education, } \% \text { of total expenditures } \\
\text { on education; }\end{array}$ & 3.3046 & 4.926 & 6.673 \\
\hline - the level of remuneration in education of output; & 0.1861 & 0.2095 & 0.2397 \\
\hline Innovation & 0.2116 & 0.3209 & 0.4268 \\
\hline - the pace of scientific and technological progress, \%; & -2.214 & -1.734 & -0.991 \\
\hline - the level of scientific research funding, \% of GDP & 0.7047 & 1.192 & 1.756 \\
\hline - the level of financing the innovation activity, $\%$ of GDP, & 0.4688 & 0.7621 & 1.1081 \\
\hline - the level of enterprises' innovation activity, $\%$ of the total number; & 16.19 & 19.93 & 25.16 \\
\hline \multicolumn{4}{|l|}{ - the level of scientific research expenditures per person, USD for } \\
\hline PPP) & 117.63 & 248.24 & 378.8 \\
\hline $\begin{array}{l}\text { - The level of inventive activity (patents and utility models), per } 1 \\
\text { million of population }\end{array}$ & 225.63 & 230.2 & 237.7 \\
\hline \multicolumn{4}{|l|}{ POLAND } \\
\hline research, education and innovation spaces & 0.4316 & 0.5071 & 0.6257 \\
\hline Education & 0.4497 & 0.5446 & 0.6353 \\
\hline $\begin{array}{l}\text { - the level of higher education coverage, per } 10 \text { thousand } \\
\text { population; }\end{array}$ & 336.37 & 383.17 & 375.0 \\
\hline $\begin{array}{l}\text { - the level of secondary education coverage, per } 10 \text { thousand } \\
\text { population; }\end{array}$ & 927.54 & 1177.7 & 1497.5 \\
\hline - the level of state funding of education, \% of output; & 2.21 & 2.855 & 3.35 \\
\hline - the level of state funding of higher education, \% of output; & 0.4123 & 0.5179 & 0.86 \\
\hline - average costs per 1 pupil (student), thousand dollars US for PPP; & 6.469 & 8.597 & 11.1 \\
\hline $\begin{array}{l}\text { - the level of capital investment in education, } \% \text { of total expenditures } \\
\text { on education; }\end{array}$ & 9.926 & 10.355 & 9.95 \\
\hline - the level of remuneration in education of output; & 0.2453 & 0.2713 & 0.29 \\
\hline Innovation & 0.3304 & 0.4371 & 0.6167 \\
\hline - the pace of scientific and technological progress, \%; & -0.2435 & 0.0044 & 1.25 \\
\hline - the level of scientific research funding, \% of GDP & 1.64 & 2.223 & 3.0 \\
\hline - the level of financing the innovation activity, \% of GDP, & 1.145 & 1.527 & 2.0 \\
\hline - The level of enterprises' innovation activity, $\%$ of the total number; & 26.19 & 34.63 & 52.5 \\
\hline - the level of innovative products' sales, $\%$ of total sales & 11.01 & 14.27 & 22.5 \\
\hline \multicolumn{4}{|l|}{ - the level of scientific research expenditures per person, USD for } \\
\hline PPP) & 29.2 & 451.16 & 665.0 \\
\hline $\begin{array}{l}\text { - the level of inventive activity (patents and utility models), per } 1 \\
\text { million of population }\end{array}$ & 10245 & 122.54 & 171.0 \\
\hline
\end{tabular}

Source: calculated by the authors. 
Construction of the probability density function of this indicator (exponential type of distribution) and calculation of statistical characteristics (Figure 7, a) for 64 EU and world countries makes it possible to calculate a scientifically sound vector of threshold values and build strategic scenarios for the growth of 'GDP per capita.'

For Poland:

1) realistic - achieving an average level between the lower threshold and lower optimal values, which corresponds to an average annual GDP growth of $2.2 \%$;

2) optimistic - reaching the level of the lower optimal value, which corresponds to the average annual GDP growth of $4.3 \%$;

3) sustainable development - achieving the average optimal value ("homeostatic plateau"), the criterion of sustainable development, which corresponds to an average annual GDP growth of $7.6 \%$.

For Ukraine, similar scenarios are restricted to the most likely achievable growth rates:

1) inertial - which corresponds to an average annual GDP growth of 3.0\%;

2) realistic - which corresponds to an average annual GDP growth of 5.0\%;

3) optimistic - which corresponds to an average annual GDP growth of 7.0\% (Figure 7, b).
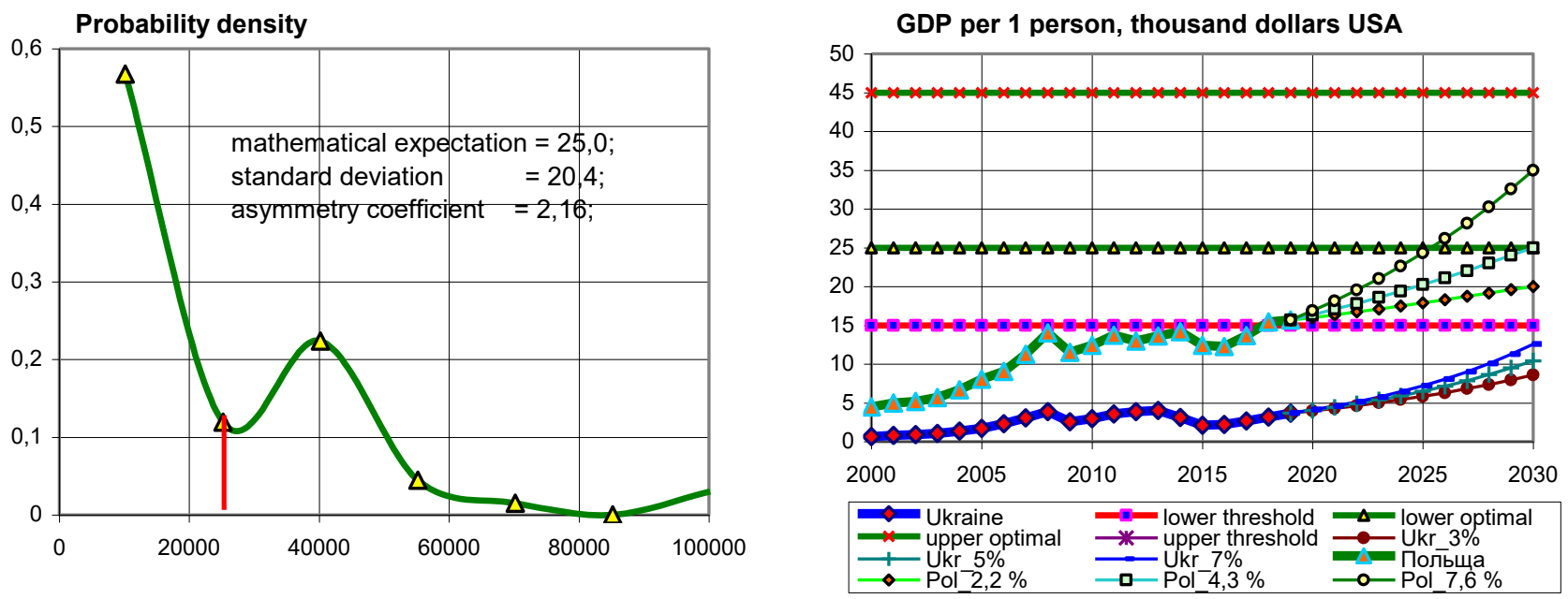

$a$

$b$

Figure 7. Determining threshold values (a) and strategic scenarios for the growth of the indicator "GDP per capita" for Ukraine and Poland

Source: own elaboration.

Thus, performing forecast calculations of the population size and the coefficient of manufacturability (ratio of GDP to output), we can obtain an assessment of strategic benchmarks of key macroeconomic indicators of research, education and innovation spaces of European integration in each year, the values of which at the end of $2030 *$ are given in Table 7. 
Table 7. Estimating strategic benchmarks of key macro indicators of research, education and innovation spaces of European integration at the end of 2030

\begin{tabular}{|c|c|c|c|c|}
\hline Indicator & 2019 & Scenario 1 & Scenario 2 & Scenario 3 \\
\hline \multicolumn{5}{|c|}{ UKRAINE } \\
\hline 1 Output, UAH billion & 8969.9 & 21350.1 & 25051.5 & 29018.8 \\
\hline 2. Coefficient of manufacturability & 0.4431 & 0.455 & 0.47 & 0.49 \\
\hline 3. Nominal GDP, UAH billion & 3974.56 & 9714.3 & 11774.2 & 14219.2 \\
\hline 4. Average annual GDP growth rate, $\%$ & 3.2 & 3.0 & 5.0 & 7.0 \\
\hline 5. GDP per 1 person, thousand dollars USA & 3.67 & 8.58 & 10.39 & 12.55 \\
\hline $\begin{array}{l}\text { 6. Average annual population size, million } \\
\text { people }\end{array}$ & 41.85 & 41.68 & 41.68 & 41.68 \\
\hline $\begin{array}{l}\text { 7. The volume of education financing, UAH } \\
\text { billion }\end{array}$ & 200.76 & 522.47 & 724.3 & 999.57 \\
\hline $\begin{array}{l}\text { 8. Volume of higher education financing, UAH } \\
\text { billion }\end{array}$ & 41.428 & 107.49 & 148.35 & 204.03 \\
\hline 9. Capital investments in education, UAH billion & 4.792 & 17.26 & 35.68 & 66.71 \\
\hline 10. Nominal salary, UAH & 10378 & 34045 & 44978 & 59626 \\
\hline 11. Number of students, million people & 1.4397 & 1.4291 & 1.5506 & 1.7123 \\
\hline 12. Number of pupils, million people & 3.8094 & 3.7581 & 4.0294 & 4.3939 \\
\hline $\begin{array}{l}\text { 13. Expenditures on scientific research, UAH } \\
\text { billion }\end{array}$ & 19.9 & 68.457 & 140.396 & 249.71 \\
\hline 14. Expenditures on innovations, UAH billion & 14.22 & 45.547 & 89.727 & 157.57 \\
\hline 15. Number of inventions, units & 9536 & 9019 & 9202 & 9501 \\
\hline \multicolumn{5}{|c|}{ POLAND } \\
\hline 1. Output, PLN billion & 4575.47 & 7690.4 & 9612.9 & 13458.1 \\
\hline 2. Coefficient of manufacturability & 0.5 & 0.5 & 0.5 & 0.5 \\
\hline 3. Nominal GDP, PLN billion & 2287.7 & 3845.2 & 4806.5 & 6729.1 \\
\hline 4. Average annual GDP growth rate, $\%$ & 4.5 & 2.2 & 4.3 & 7.6 \\
\hline 5. GDP per 1 person, thousand dollars USA & 15.69 & 20.0 & 25.0 & 35.0 \\
\hline $\begin{array}{l}\text { 6. Average annual population size, million } \\
\text { people }\end{array}$ & 38.419 & 38.268 & 38.268 & 38.268 \\
\hline 7. The volume of education financing, PLN billion & 86.34 & 170.0 & 274.4 & 450.85 \\
\hline $\begin{array}{l}8 \text {. Volume of higher education financing, PLN } \\
\text { billion }\end{array}$ & 16.5 & 31.71 & 49.79 & 115.74 \\
\hline 9. Capital investments in education, PLN billion & 8.4 & 16.87 & 28.42 & 44.86 \\
\hline 10. Nominal salary, PLN & 4944 & 8238 & 11387 & 17040 \\
\hline 11. Number of students, million people & 1.2057 & 1.2934 & 1.4734 & 1.4419 \\
\hline 12. Number of pupils, million people & 3.0658 & 3,5666 & 4.5286 & 5.7582 \\
\hline $\begin{array}{l}\text { 13. Expenditures on scientific research, UAH } \\
\text { billion }\end{array}$ & 30.28 & 63,06 & 106.87 & 201.87 \\
\hline 14. Expenditures on innovations, PLN billion & 21.52 & 44,03 & 73.38 & 134.78 \\
\hline 15. Number of inventions, units & 3555 & 3939 & 4712 & 6575 \\
\hline
\end{tabular}

The calculated strategic guidelines of indicators and key macro indicators of research, education and innovation spaces of European integration in each year are a strategic plan for this area development and are the best criterion for estimating how effectively the 
government and authorities of each country act by monitoring relevant indicators and macro indicators.

\section{Conclusions}

There were analysed the approaches to scientific elaboration and formation of the Strategy of integration of Ukraine and Poland into the research, education and innovation spaces of the $\mathrm{EU}$, and the absence of a systematic approach was determined. No paper considers proposals for its own list of indicators and its own calculation of the current level of research, education and innovation spaces of European integration of Ukraine and Poland. There were formulated the remarks to the main tool for measuring the innovative development of the EU countries the European Innovation Scoreboard (EIS), which concern both the list of evaluation indicators and the methodology.

There is proposed a systematic assessment of the level of research, education and innovation spaces of European integration of Ukraine and Poland, which consists of two subsystems: "education" and "innovation", for which a coordinated list of indicators for Poland and Ukraine has been developed. A total of 14 indicators are presented, 7 in each subsystem, including as the most important resulting indicator of qualitative changes in the economy, including innovation - the pace of scientific and technological progress.

For all indicators there were scientifically substantiated the limits of safe existence - vectors of threshold values at different levels through the construction of probability density functions, calculation of statistical characteristics, determination of affiliation to the type of distribution (normal, lognormal, exponential) and formalized calculation by "t-criterion" method. Such presentation makes it possible to identify the level of security of research, education and innovation spaces of European integration as a status of the system's security and its ability to adapt to new challenges.

To quantify the level of security of research, education and innovation spaces of European integration, a modern universal identification methodology was used, which provided a multiplicative form of the integrated index, a combined method of rationing and dynamic weights. Based on the proposed methodology, a multifactor hierarchical mathematical model for identifying the level of research, education and innovation spaces of European integration of Ukraine and Poland was developed and modeling was performed, which determined the current state of Ukraine as critical and tat of Poland as crisis.

Simultaneous hierarchical convolution of indicators and their thresholds makes it possible to compare integrated indices with integrated thresholds and scientifically substantiate the gradations of integrated indices as a critical, crisis and optimal states, as well as to identify strategic scenarios for medium-term development.

The calculation of deviations of integrated indices and their indicators from the criterion of sustainable development - the average value of "homeostatic plateau" - allows, by means of 
defining imbalances, substantiating a list and importance of threats by the maximum deviation, and the calculation of elasticity coefficients - the importance of their impact on the level of education and innovation development in the security dimension. Such information provides substantiated directions of structural transformation of research, education and innovation spaces of European integration of Ukraine and Poland. Out of 14 indicators of research, education and innovation spaces, 12 indicators pose a critical threat to Ukraine and 9 indicators - to Poland.

One-scale comparison of integrated indices of education and innovation makes it possible to carry out the goal-setting stage, identify possible strategic development scenarios and build the desired development trajectories, i.e., to implement the principle of strategizing "the future is determined by the future trajectory." Thus, knowledge of the desired values of integrated indices in each year makes it possible, through their decomposition by the method of adaptive control from the theory of management, to justify the values of indicators that provide the desired growth trajectory and achieve definite goals of research, education and innovation spaces.

Constructing the probability density function for the indicator "GDP per 1 person / thousand USD" at the current exchange rate and determining its vector of threshold values made it possible to justify the strategic values of indicators and key macro indicators until 2030 according to development scenarios: for Poland - 20, 25 and 35 thousand US dollars with the corresponding average annual rate of real GDP growth - 2.2; 4.3 and 7.6\%; for Ukraine - 8.6; 10.4 and 12.5 thousand US dollars with the corresponding average annual growth rates of real GDP - 3, 5 and $7 \%$.

Thus, scientifically sound future values of indicators and macro indicators are the goal of strategic planning and the best criterion to estimate the effectiveness of authorities' and government's actions by monitoring current integrated indices and relevant indicators and macro indicators.

\section{Funding}

This study was commissioned by the Department of Economics of the National Academy of Sciences of Ukraine as a program-targeted and competitive theme of the National Academy of Sciences of Ukraine "Strategic directions of Ukraine's integration into research, education and innovation spaces of the EU: scientific and institutional support" (code: II-06-19) within the project "Supporting the priority scientific research and scientific and technical (experimental) developments of the Department of Economics of the National Academy of Sciences of Ukraine". 


\section{References}

Aleksander, A., Krawczyk, D., Kuzior, A., \& Kwilinski, A. (2020). The Conditions Affecting the Functioning of the Mass Media and Social Media Based on Empirical Research Conducted in Ukraine. In Khalid S. Soliman (Ed.), Proceedings of the 36th International Business Information Management Association (IBIMA) 4-5 November 2020 (pp. 10330-10342). Granada, Spain: IBIMA Publishing.

Arefieva, O., Polous, O., Arefiev, S., Tytykalo, V., \& Kwilinski, A. (2021). Managing sustainable development by human capital reproduction in the system of company's organizational behaviour. IOP Conference Series: Earth and Environmental Science, 628, 012039.

Babiy, G.Y. (2015). Development of the Border Areas in the Context of Activation of InvestmentInnovation Practices in Ukrainian-Polish Transborder Region. Regional Economy, 1, 130-135.

Boiko, V., Kwilinski, A., Misiuk, M., \& Boiko, L. (2019). Competitive Advantages of Wholesale Markets of Agricultural Products as a Type of Entrepreneurial Activity: The Experience of Ukraine and Poland. Economic Annals-XXI, 175(1-2), 68-72. https://doi.org/10.21003/ea.V175-12

Bogachov, S., Kwilinski, A., Miethlich, B., Bartosova, V., \& Gurnak, A. (2020). Artificial Intelligence Components and Fuzzy Regulators in Entrepreneurship Development. Entrepreneurship and Sustainability Issues, 8(2), 487-499. http://doi.org/10.9770/jesi.2020.8.2(29)

Borychowski, M., Stępień, S., Polcyn, J., Tošović-Stevanović, A., Ćalović, D., Lalić, G., \& Žuža, M. (2020). Socio-Economic Determinants of Small Family Farms' Resilience in Selected Central and Eastern European Countries. Sustainability, 12(24), 10362. doi:10.3390/su122410362

Borshchevskyi, V.V., Voloshyn, V.I., \& Babii, H.la. (2017). Investytsiino-innovatsiina diialnist v ukrainskopolskomu transkordonnomu rehioni: yevrointehratsiinyi kontekst [Investment and Innovation Activities in the Ukrainian-Polish Cross-Border Region: The European Integration Context]. Stratehichna panorama, 2, 38-45. [in Ukrainian].

Chessa, A., Morescalchi, A., Pammolli, F., Penner, O., Petersen, A.M., \& Riccaboni, M. (2013). Is Europe Evolving toward an Integrated Research Area? Science, 339(6120), 650-651. https://doi.org/10.1126/ science.1227970

Chygryn, O., Bilan, Y., \& Kwilinski, A. (2020). Stakeholders of Green Competitiveness: Innovative Approaches for Creating Communicative System. Marketing and Management of Innovations, 3, 356-368. https://doi.org/10.21272/mmi.2020.3-26

Cyfert, S., Glabiszewski, W., Krzakiewicz, K., \& Zastempowski, M. (2020). The Importance of Dynamic Capabilities in the Processes of Alignment of Chemical Industry Enterprises to Changes in the Environment. Przemysl Chemiczny, 99(6), 953-956.

Cyfert, S., Chwiłkowska-Kubala, A., Szumowski, W., \& Miśkiewicz, R. (2021). The process of developing dynamic capabilities: The conceptualization attempt and the results of empirical studies. PLOS ONE, 16(4), e0249724. https://doi.org/10.1371/journal.pone.0249724

Czakon, W., Kawa, A., \& Scott, S. (2020). Network Orientation of Logistics Service Providers: The Construct, Dimensionality and Measurement Scale. International Journal of Logistics Research and Applications, 23(5), 474-492. https://doi.org/10.1080/13675567.2019.1705260

Czyżewski, B., Matuszczak, A., \& Miskiewicz, R. (2019). Public goods versus the farm price-cost squeeze: shaping the sustainability of the EU's common agricultural policy. Technological and Economic Development of Economy, 25(1), 82-102. https://doi.org/10.3846/tede.2019.7449

Czyżewski, B., Matuszczak, A., Polcyn, J., Smędzik-Ambroży, K., \& Staniszewski, J. (2020). Deadweight loss in environmental policy: The case of the European Union member states. Journal of Cleaner Production, 260, 121064. https://doi.org/10.1016/j.jclepro.2020.121064 
Dalevska, N., Khobta, V., Kwilinski, A., \& Kravchenko, S. (2019). A Model for Estimating Social and Economic Indicators of Sustainable Development. Entrepreneurship and Sustainability Issues, 6(4), 1839-1860. https://doi.org/10.9770/jesi.2019.6.4(21)

Dementyev, V.V., \& Kwilinski, A. (2020). Institutsionalnaya sostavlyayuschaya izderzhek proizvodstva [Institutional Component of Production Costs]. Journal of Institutional Studies, 12(1), 100-116. https://doi.org/10.17835/2076-6297.2020.12.1.100-116

Dementyev, V., Dalevska, N., \& Kwilinski, A. (2021). Institutional Determinants of Structuring the World Political and Economic Space. In Khalid S. Soliman (Ed.), Proceedings of the 37th International Business Information Management Association (IBIMA), 1-2 April 2021 (pp. 2187-2199). Cordoba, Spain: IBIMA Publishing.

Dyduch, W. (2019a). Entrepreneurial Strategy Stimulating Value Creation: Conceptual Findings and Some Empirical Tests. Entrepreneurial Business and Economics Review, 7(3), 65-82. https://doi.org/10.15678/EBER.2019.070304

Dyduch, W. (2019b). Organizational Design Supporting Innovativeness. Przeglqd Organizacji, 6, 16-23. https://doi.org/10.33141/po.2019.06.02

Dzwigol, H. (2016). Modelling of Restructuring Process. Zeszyty Naukowe. Organizacja i Zarzqdzanie, 99, 89-106.

Dzwigol, H. (2019a). The Concept of the System Approach of the Enterprise Restructuring Process. Virtual Economics, 2(4), 46-70. https://doi.org/10.34021/ve.2019.02.04(3)

Dzwigol, H. (2019b). Research Methods and Techniques in New Management Trends: Research Results. Virtual Economics, 2(1), 31-48. https://doi.org/10.34021/ve.2019.02.01(2)

Dzwigol, H. (2020a). Innovation in Marketing Research: Quantitative and Qualitative Analysis. Marketing and Management of Innovations, 1, 128-135. http://doi.org/10.21272/mmi.2020.1-10

Dzwigol, H. (2020b). Methodological and Empirical Platform of Triangulation in Strategic Management. Academy of Strategic Management Journal, 19(4), 1-8.

Dźwigot, H. (2021a). Contemporary Model of Market Economy under Conditions of Uncertainty. In Khalid S. Soliman (Ed.), Proceedings of the 37th International Business Information Management Association (IBIMA), 1-2 April 2021 (pp. 3769-3778). Cordoba, Spain: IBIMA Publishing.

Dzwigol, H. (2021b). Meta-Analysis in Management and Quality Sciences. Marketing and Management of Innovations, 1, 324-335. http://doi.org/10.21272/mmi.2021.1-25

Dzwigol, H., \& Wolniak, R. (2018). Controlling w procesie zarządzania chemicznym przedsiębiorstwem produkcyjnym [Controlling in the management process of a chemical industry production company]. Przemys/ Chemiczny, 97(7), 1114-1116. https://doi.org/10.15199/62.2018.7.15

Dzwigol, H., \& Dźwigoł-Barosz, M. (2018). Scientific Research Methodology in Management Sciences. Financial and Credit Activity: Problems of Theory and Practice, 2(25), 424-437. https://doi.org/10.18371/fcaptp.v2i25.136508

Dzwigol, H., \& Dzwigol-Barosz, M. (2020). Sustainable Development of the Company on the Basis of Expert Assessment of the Investment Strategy. Academy of Strategic Management Journal, 19(5), 1-7.

Dzwigol, H., Shcherbak, S., Semikina, M., Vinichenko, O., \& Vasiuta, V. (2019a). Formation of Strategic Change Management System at an Enterprise. Academy of Strategic Management Journal, 18(SI1), $1-8$. 
Dzwigol, H., Aleinikova, O., Umanska, Y., Shmygol, N., \& Pushak, Y. (2019b). An Entrepreneurship Model for Assessing the Investment Attractiveness of Regions. Journal of Entrepreneurship Education, 22(1S), 1-7.

Dzwigoł, H., Dzwigoł-Barosz, M., Zhyvko, Z., Miskiewicz, R., \& Pushak, H. (2019c). Evaluation of the Energy Security as a Component of National Security of the Country. Journal of Security and Sustainability Issues, 8(3), 307-317. http://doi.org/10.9770/jssi.2019.8.3(2)

Dzwigol, H., Dźwigoł-Barosz, M., \& Kwilinski, A. (2020a). Formation of Global Competitive Enterprise Environment Based on Industry 4.0 Concept. International Journal of Entrepreneurship, 24(1), 1-5.

Dzwigol, H., Dzwigol-Barosz, M., Miskiewicz, R., \& Kwilinski, A. (2020b). Manager Competency Assessment Model in the Conditions of Industry 4.0. Entrepreneurship and Sustainability Issues, 7(4), 2630-2644. https://doi.org/10.9770/jesi.2020.7.4(5)

Furmaniak, S., Gauden, P.A., Patrykiejew, A., Miśkiewicz, R., \& Kowalczyk, P. (2018). Carbon Nanohorns as Reaction Nanochambers - a Systematic Monte Carlo Study. Scientific Reports, 15407. https://doi.org/10.1038/s41598-018-33725-z

Furmaniak, S., Gauden, P.A., Patrykiejew, A., Miskiewicz, R., \& Kowalczyk, P. (2019a). The Effects of Confinement in Pores Built of Folded Graphene Sheets on the Equilibrium of Nitrogen Monoxide Dimerisation Reaction. Journal of Physics Condensed Matter, 31(13), 135001, 1-12. https://doi.org/10.1088/1361-648X/aaffb3

Furmaniak, S., Gauden, P.A., Patrykiejew, A., Szymański, G., Miśkiewicz, R., \& Kowalczyk, P. (2019b). In Silico Study on the Effects of Carbonyl Groups on Chemical Equilibrium of Reactions with a Polar Product Occurring under Confinement in Pores of Activated Carbons. Chemical Engineering Communications, 1-12. https://doi.org/10.1080/00986445.2019.1700115

EIS. (2020). Methodology Report. Retrieved from https://ec.europa.eu/docsroom/documents/41861

European Innovation Scoreboards. (2020). European Commission, Directorate-General for Internal Market, Industry, Entrepreneurship and SMEs. Retrieved from http://ec.europa.eu/growth/ industry/innovation/facts-figures/scoreboards

Gorynia, M., Trąpczyński, P., \& Bytniewski, S. (2019). The Concepts of Strategy and Business Models in Firm Internationalization Research: Towards a Research Agenda. International Entrepreneurship Review, 5(2), 7-21. https://doi.org/10.15678/ier.2019.0502.01

Gorynia, M. (2019). Competition and Globalisation in Economic Sciences. Selected Aspects. Economics and Business Review, 5(3), 118-133. https://doi.org/10.18559/ebr.2019.3.7

Heiets, V.M. et al. (Eds.). (2015). Innovatsiina Ukraina 2020: natsionalna dopovid [Innovative Ukraine 2020: The National Report]. Kyiv: NAN Ukrainy. [in Ukrainian].

Kaźmierczyk, J., \& Chinalska, A. (2018). Flexible forms of employment, an opportunity or a curse for the modern economy? Case study: banks in Poland. Entrepreneurship and Sustainability Issues 6(2), 782-798. https://doi.org/10.9770/jesi.2018.6.2(21)

Khan, Ye., \& Sliusarenko, A. (2016). Intehratsiini protsesy Ukraina - Yevropeiskyi soiuz: na prykladi spivpratsiu sferi vyshchoi osvity [Ukraine-European Union Integration Processes: On the Example of Cooperation in the Field of Higher Education]. Visnyk Kyivskoho natsionalnoho universytetu imeni Tarasa Shevchenka. Istoriia, 4, 80-84. [in Ukrainian].

Kharazishvili, Y.M. (2018). Vnesok naukovo-tekhnolohichnoho prohresu v ekonomichne zrostannia promyslovykh rehioniv Ukrainy [The Contribution of Scientific and Technological Progress to the Economic Growth of Industrial Regions of Ukraine]. Economy of Industry, 83, 5-20. http://doi.org/10.15407/econindustry2018.03.005 [in Ukrainian]. 
Kharazishvili, Y. (2019). Systemic Security of Sustainable Development: Assessment Tools, Reserves and Strategic Implementation Scenarios: Monograph. Kyiv: Institute of Industrial Economics, National Academy of Sciences of Ukraine. [in Ukrainian].

Kharazishvili, Y., Grishnova, O., \& Kamińska, B. (2019). Standards of Living in Ukraine, Georgia, and Poland: Identification and Strategic Planning. Virtual Economics, 2(2), 7-36. https://doi.org/10.34021/ve.2019.02.02(1)

Kharazishvili, Y., Kwilinski, A., Grishnova, O., \& Dzwigol, H. (2020). Social Safety of Society for Developing Countries to Meet Sustainable Development Standards: Indicators, Level, Strategic Benchmarks (with Calculations Based on the Case Study of Ukraine). Sustainability, 12(21), 8953. https://doi.org/10.3390/su12218953

Kharazishvili, Y., Kwilinski, A., Sukhodolia, O., Dzwigol, H., Bobro, D., \& Kotowicz, J. (2021a). Systemic Approach for Estimating and Strategizing Energy Security: The Case of Ukraine. Energies, 14(8), 2126. https://doi.org/10.3390/en14082126

Kharazishvili, Y., Kwilinski, A., Dzwigol, H., Liashenko, V., \& Lukaszczyk, L. (2021b). Identification and Comparative Analysis of Ukrainian and Polish Scientific-Educational and Innovative Spaces of European Integration. In Khalid S. Soliman (Ed.), Proceedings of the 37th International Business Information Management Association (IBIMA), 1-2 April 2021 (pp. 3707-3721). Cordoba, Spain: IBIMA Publishing.

Khaustov, V.K. (2018). Innovatsiinyi vymir kursu Ukrainy na yevrointehratsiiu [Innovative Dimension of Ukraine's Course on European Integration]. Ekonomika i prohnozuvannia, 2, 135-150. https://doi.org/10.15407/eip2018.02.135 [in Ukrainian].

Khrapkina, V., Kwilinski, A., Polcyn, J., Pająk, K., Stratonov, V., \& Kobets, V. (2021). Creation of a Reserve Fund as a Tool for Ensuring the Financial Security of an Enterprise. In Khalid S. Soliman (Ed.), Proceedings of the 37th International Business Information Management Association (IBIMA), 1-2 April 2021 (pp. 3610-3627). Cordoba, Spain: IBIMA Publishing.

Klimas, P., Czakon, W., Kraus, S., Kailer, N., \& Maalaoui, A. (2020). Entrepreneurial Failure: A Synthesis and Conceptual Framework of its Effects. European Management Review. https://doi.org/10.1111/emre.12426

Koibichuk, V., Ostrovska, N., Kashiyeva, F., \& Kwilinski, A. (2021). Innovation Technology and Cyber Frauds Risks of Neobanks: Gravity Model Analysis. Marketing and Management of Innovations, 1, 253-265. http://doi.org/10.21272/mmi.2021.1-19

Kondratenko, V., Okopnyk, O., Ziganto, L., \& Kwilinski, A. (2020). Innovation Development of Public Administration: Management and Legislation Features. Marketing and Management of Innovations, 1, 87-94. https://doi.org/10.21272/mmi.2020.1-06

Kraievska, O. (2014). Uhoda pro asotsiatsiiu mizh Ukrainoiu ta YeS: spivpratsia u sferi osvity i nauky [EU-Ukraine Association Agreement: Cooperation in Education and Science]. Visnyk Lvivskoho universytetu. Seriia mizhnarodni vidnosyny, 36(2), 90-97. [in Ukrainian].

Kuzior, A., Kwilinski, A., \& Tkachenko, V. (2019). Sustainable Development of Organizations Based on the Combinatorial Model of Artificial Intelligence. Entrepreneurship and Sustainability, 7(2), 13531376. http://doi.org/10.9770/jesi.2019.7.2(39)

Kuzior, A, Kwilinski, A, \& Hroznyi, I. (2021). The Factorial-Reflexive Approach to Diagnosing the Executors' and Contractors' Attitude to Achieving the Objectives by Energy Supplying Companies. Energies, 14(9), 2572. https://doi.org/10.3390/en14092572

Kwilinski, A. (2018a). Mechanism of Formation of Industrial Enterprise Development Strategy in the Information Economy. Virtual Economics, 1(1), 7-25. https://doi.org/10.34021/ve.2018.01.01(1) 
Kwilinski, A. (2018b). Mechanism of Modernization of Industrial Sphere of Industrial Enterprise in Accordance with Requirements of the Information Economy. Marketing and Management of Innovations, 4, 116-128. http://doi.org/10.21272/mmi.2018.4-11

Kwilinski, A. (2019). Implementation of Blockchain Technology in Accounting Sphere. Academy of Accounting and Financial Studies Journal, 23(SI2), 1-6.

Kwilinski, A., Tkachenko, V., \& Kuzior, A. (2019a). Transparent Cognitive Technologies to Ensure Sustainable Society Development. Journal of Security and Sustainability Issues, 9(2), 561-570 http://doi.org/10.9770/jssi.2019.9.2(15)

Kwilinski, A., Drobyazko, S., \& Derevyanko, B. (2019b). Synergetic and Value Effects in Corporate Mergers and Acquisitions of International Companies. In Khalid S. Soliman (Ed.), Proceedings of the 34th International Business Information Management Association Conference (IBIMA) 13-14 November 2019. Vision 2025: Education Excellence and Management of Innovations through Sustainable Economic Competitive Advantage in 2019 (pp. 9467-9471). Madrid, Spain: IBIMA Publishing.

Kwilinski, A., Dalevska, N., Kravchenko, S., Hroznyi, I., Kovalenko, I. (2019c). Formation of the Entrepreneurship Model of E-Business in the Context of the Introduction of Information and Communication Technologies. Journal of Entrepreneurship Education, 22(SI1), 1528-2651-22-S1337: 1-7.

Kwilinski, A., Ruzhytskyi, I., Patlachuk, V., Patlachuk, O., \& Kaminska, B. (2019d). Environmental Taxes as a Condition of Business Responsibility in the Conditions of Sustainable Development. Journal of Legal, Ethical and Regulatory Issues, 22(SI2) 1544-0044-22-SI-2-354: 1-6.

Kwilinski, A., Volynets, R., Berdnik, I., Holovko, M., \& Berzin, P. (2019e). E-Commerce: Concept and Legal Regulation in Modern Economic Conditions. Journal of Legal, Ethical and Regulatory Issues, 22(SI2), 1544-0044-22-SI-2-357: 1-6.

Kwilinski, A., Pajak, K., Halachenko, O., Vasylchak, S., Pushak, Ya., \& Kuzior, P. (2019f). Marketing Tools for Improving Enterprise Performance in the Context of Social and Economic Security of the State: Innovative Approaches to Assessment. Marketing and Management of Innovations, 4, 172-181. http://doi.org/10.21272/mmi.2019.4-14

Kwilinski, A., \& Kuzior, A. (2020). Cognitive Technologies in the Management and Formation of Directions of the Priority Development of Industrial Enterprises. Management Systems in Production Engineering, 28(2), 119-123. http://doi.org/10.1515/mspe-2019-0020

Kwilinski, A., Vyshnevskyi, O., \& Dzwigol, H. (2020a). Digitalization of the EU Economies and People at Risk of Poverty or Social Exclusion. Journal of Risk and Financial Management, 13(7), 142. https://doi.org/10.3390/jrfm13070142

Kwilinski, A., Zaloznova, Y., Trushkina, N., \& Rynkevych, N. (2020b). Organizational and Methodological Support for Ukrainian Coal Enterprises Marketing Activity Improvement. E3S Web of Conferences, 168, 00031. https://doi.org/10.1051/e3sconf/202016800031

Kwilinski, A., Dielini, M., Mazuryk, O., Filippov, V., \& Kitseliuk, V. (2020c). System Constructs for the Investment Security of a Country. Journal of Security and Sustainability Issues, 10(1), 345-358. https://doi.org/10.9770/jssi.2020.10.1(25)

Kwilinski, A., Shteingauz, D., \& Maslov, V. (2020d). Financial and Credit Instruments for Ensuring Effective Functioning of the Residential Real Estate Market. Financial and Credit Activities: Problems of Theory and Practice, 3(34), 133-140. Retrieved from https://fkd.ubs.edu.ua/index.php/fkd/article/view/3023 
Kwilinski, A., Slatvitskaya, I., Dugar, T., Khodakivska, L., \& Derevyanko, B. (2020e). Main Effects of Mergers and Acquisitions in International Enterprise Activities. International Journal of Entrepreneurship, 24(Special Issue), 1-8.

Kwilinski, A., Litvin, V., Kamchatova, E., Polusmiak, J., \& Mironova, D. (2021). Information Support of the Entrepreneurship Model Complex with the Application of Cloud Technologies. International Journal of Entrepreneurship, 25(1), 1-8.

Kyrylov, Y, Hranovska, V, Boiko, V, Kwilinski, A, \& Boiko, L. (2020). International Tourism Development in the Context of Increasing Globalization Risks: On the Example of Ukraine's Integration into the Global Tourism Industry. Journal of Risk and Financial Management, 13(12), 303. https://doi.org/10.3390/jrfm13120303

Luhovyi, V., \& Talanova, Zh. (2017). Nauka v universytetakh, universytety v nautsi u svitovomu doslidnytskomu prostori [Science in Universities, Universities in Science in the World Research Space]. Vyshcha osvita Ukrainy, 1, 42-50. [in Ukrainian].

Lyashenko, V., \& Pidorycheva, I. (2019). The Formation of Interstate and Cross-Border ScientificEducational and Innovative Spaces between Ukraine and the European Union Member States in the Digital Economy. Virtual Economics, 2(2), 48-58. https://doi.org/10.34021/ve.2019.02.02(3)

Lakhno, V., Malyukov, V., Bochulia, T., Hipters, Z., Kwilinski, A., \& Tomashevska, O. (2018). Model of Managing of the Procedure of Mutual Financial Investing in Information Technologies and Smart City Systems. International Journal of Civil Engineering and Technology, 9(8), 1802-1812.

Lyulyov, O., \& Pimonenko, T. (2017a). Lotka-Volterra model as an instrument of the investment and innovative processes stability analysis. Marketing and Management of Innovations, 1, 159-169. doi: 10.21272/mmi.2017.1-14

Lyulyov, O., \& Shvindina, H. (2017b). Stabilisation Pentagon Model: application in the management at macro- and micro-levels. Problems and Perspectives in Management, 15(3), 42-52. doi:10.21511/ppm.15(3).2017.04

Lyulyov, O., Chygryn, O., \& Pimonenko, T. (2018). National brand as a marketing determinant of macroeconomic stability. Marketing and Management of Innovations, 3, 142-152, doi: 10.21272/mmi.2018.3-12

Lyulyov, O., Us, Y., Pimonenko, T., Kwilinski, A., Vasylieva, T., Dalevska, N., Polcyn, J., \& Boiko, V. (2020a). The Link between Economic Growth and Tourism: Covid-19 Impact. In Khalid S. Soliman (Ed.), Proceedings of the 36th International Business Information Management Association (IBIMA) 4-5 November 2020. (pp. 8070-8086). Granada, Spain: IBIMA Publishing.

Lyulyov, O., Pimonenko, T., Kwilinski, A., Us, Y., Arefieva, O., Akimov, O., \& Pudryk, D. (2020b). Government Policy on Macroeconomic Stability: Case for Low- and Middle- Income Economies. In Khalid S. Soliman (Ed.), Proceedings of the 36th International Business Information Management Association (IBIMA) 4-5 November 2020 (pp. 8087-8101). Granada, Spain: IBIMA Publishing.

Lyulyov, O., Pimonenko, T., Kwilinski, A., Dzwigol, H., Dzwigol-Barosz, M., Pavlyk, V., \& Barosz, P. (2021). The Impact of the Government Policy on the Energy Efficient Gap: The Evidence from Ukraine. Energies, 14(2), 373. https://doi.org/10.3390/en14020373

Makkonen, T., \& Rohde, S. (2016). Cross-Border Regional Innovation Systems: Conceptual Backgrounds, Empirical Evidence and Policy Implications. European Planning Studies, 24(9), 16231642. https://doi.org/10.1080/09654313.2016.1184626

Marek, P., Titze, M., Fuhrmeister, C., \& Blum, U. (2017). R\&D Collaborations and the Role of Proximity. Regional Studies, 51(12), 1761-1773. https://doi.org/10.1080/00343404.2016.1242718 
Matiushenko, I.I., Khaustova, V.I., \& Kniaziev, S.I. (2017). Instytutsiina pidtrymka naukovoinnovatsiinoho rozvytku pry formuvanni yedynoho doslidnytskoho prostoru v krainakh YeS $\mathrm{i}$ Ukraini [Institutional Support for Scientific and Innovative Development While Shaping a Single Research Space in the EU and Ukraine]. Nauka innov., 13(2), 5-26. https://doi.org/10.15407/scin13.02.005 [in Ukrainian].

Melnychenko, O. (2020). Is Artificial Intelligence Ready to Assess an Enterprise's Financial Security? Journal of Risk and Financial Management, 13(9), 191. https://doi.org/10.3390/jrfm13090191

Melnychenko, O. (2021). The Energy of Finance in Refining of Medical Surge Capacity. Energies, 14, 210. https://doi.org/10.3390/en14010210

Melnychenko, O. (2019). Application of artificial intelligence in control systems of economic activity. Virtual Economics, 2(3), 30-40. https://doi.org/10.34021/ve.2019.02.03(3)

Mlaabdal, S., Chygryn, O., Kwilinski, A., Muzychuk, O., \& Akimov, O. (2020). Economic Growth and Oil Industry Development: Assessment of the Interaction of National Economy Indicators. In Khalid S. Soliman (Ed.), Proceedings of the 36th International Business Information Management Association (IBIMA) 4-5 November 2020 (pp. 8102-8114). Granada, Spain: IBIMA Publishing.

Miskiewicz, R. (2018). The Importance of Knowledge Transfer on the Energy Market. Polityka Energetyczna, 21(2), 49-62. http://dx.doi.org/10.24425\%2F122774

Miskiewicz, R. (2019). Challenges Facing Management Practice in the Light of Industry 4.0: The Example of Poland. Virtual Economics, 2(2), 37-47. https://doi.org/10.34021/ve.2019.02.02(2)

Miskiewicz, R. (2020a). Internet of Things in Marketing: Bibliometric Analysis. Marketing and Management of Innovations, 3, 371-381. http://doi.org/10.21272/mmi.2020.3-27

Miskiewicz, R. (2020b). Efficiency of Electricity Production Technology from Post-Process Gas Heat: Ecological, Economic and Social Benefits. Energies, 13(22), 6106. https://doi.org/10.3390/en13226106

Miśkiewicz, R, \& Wolniak, R. (2020). Practical Application of the Industry 4.0 Concept in a Steel Company. Sustainability, 12(14), 5776. https://doi.org/10.3390/su12145776

Opanasiuk, Yu. (2017). Problemy rozvytkumizhnarodnoho akademichnoho spivrobitnytstva [Problems of Development of International Academic Cooperation]. Vyshcha osvita Ukrainy, 2, 64-70. [in Ukrainian].

Paniotto, V.I., Maksymenko, V.S., \& Kharchenko, N.M. (2004). Statystychnyi analiz sotsiolohichnykh danykh [Statistical Analysis of Sociological Data]. Kyiv, Ukraine: Vyd. Dim "KM Akademiya." [in Ukrainian].

Pająk, K., Kamińska, B., \& Kvilinskyi, O. (2016). Modern Trends of Financial Sector Development under the Virtual Regionalization Conditions. Financial and Credit Activity: Problems of Theory and Practice, 2(21), 204-217. https://doi.org/10.18371/fcaptp.v2i21.91052

Pająk, K., Kvilinskyi, O., Fasiecka, O., \& Miskiewicz, R. (2017). Energy security in regional policy in Wielkopolska region of Poland. Economics and Environment, 2(61), 122-138.

Pimonenko, T., \& Lyulyov, O. (2019). Marketing strategies of green investments: main provisions and basic features. Herald of Ternopil National Economic University, (1), 177-185. doi: https://doi.org/10.35774/visnyk2019.01.177.

Polcyn, J., \& Czyżewski, B. (2016). Maximizing the quality of education by measuring the educational added value in secondary school technical type on the basis of exam results. Management, 20(2), 360-378. https://doi.org/10.1515/manment-2015-0070 
Prokopenko, O., \& Miskiewicz, R. (2020). Perception of "Green Shipping" in the Contemporary Conditions. Entrepreneurship and Sustainability Issues, 8(2), 269-284. https://doi.org/10.9770/jesi.2020.8.2(16)

Radosevic, S., \& Stancova, K. (2015). External Dimensions of Smart Specialisation: Opportunities and Challenges for Trans-Regional and Transnational Collaboration in the EU-13. S3 Working paper series no.09/2015. Luxembourg: IPTS-JRC Seville, Publications Office.

Saługa, P.W., Szczepańska-Woszczyna, K., Miśkiewicz, R., \& Chłąd, M. (2020). Cost of Equity of CoalFired Power Generation Projects in Poland: Its Importance for the Management of DecisionMaking Process. Energies. 13(18), 4833.https://doi.org/10.3390/en13184833

Savchenko, T., Basiurkina, N., Rodina, O., \& Kwilinski, A. (2019). Improvement of the Assessment Methods of Product Competitiveness of the Specialized Poultry Enterprises. Management Theory and Studies for Rural Business and Infrastructure Development, 41(1), 43-61. https://doi.org/10.15544/mts.2019.05

State Statistics Service of Poland. (2020). Retrieved from https://stat.gov.pl/obszarytematyczne/roczniki-statystyczne/roczniki-statystyczne/rocznik-statystyczny-rzeczypospolitejpolskiej-2006,2,1.html

State Statistics Service of Ukraine. (2020). Retrieved from http://www.ukrstat.gov.ua/

Shkodina, I., Melnychenko, O., \& Babenko, M. (2020). Quantitative Easing Policy and Its Impact on the Global Economy. Financial and Credit Activity: Problems of Theory and Practice, 2(33), 513-521. http://dx.doi.org/10.18371/fcaptp.v2i33.207223

Sukhodolya, O., Kharazishvili, Y., \& Bobro, D., (2020). Methodological Principles of Identification and Strategy of the Level of Energy Security of Ukraine. Ekonomika Ukrainy, 6(703), 20-42. https://doi.org/10.15407/economyukr.2020.06.020 [in Ukrainian].

Tkachenko, V., Kwilinski, A., Korystin, O., Svyrydiuk, N., \& Tkachenko, I. (2019a). Assessment of Information Technologies Influence on Financial Security of Economy. Journal of Security and Sustainability, 8(3), 375-385. http://doi.org/10.9770/jssi.2019.8.3(7)

Tkachenko, V., Kwilinski, A., Klymchuk, M., \& Tkachenko, I. (2019b). The Economic-Mathematical Development of Buildings Construction Model Optimization on the Basis of Digital Economy. Management Systems in Production Engineering, 27(2), 119-123. http://doi.org/10.1515/mspe2019-0020

Tkachenko, V., Kwilinski, A., Tkachenko, I., \& Puzyrova, P. (2019c). Theoretical and Methodical Approaches to the Definition of Marketing Risks Management Concept at Industrial Enterprises. Marketing and Management of Innovations, 2, 228-238. http://doi.org/10.21272/mmi.2019.2-20

Tkachenko, V., Kwilinski, A., Kaminska, B., Tkachenko, I., \& Puzyrova, P. (2019d). Development and Effectiveness of Financial Potential Management of Enterprises in Modern Conditions. Financial and Credit Activity: Problems of Theory and Practice, 3(30), 85-94. https://doi.org/10.18371/fcaptp.v3i30.179513

Tkachenko, V., Kuzior, A., \& Kwilinski, A. (2019e). Introduction of artificial intelligence tools into the training methods of entrepreneurship activities. Journal of Entrepreneurship Education, 22(6), 110.

Trąpczyński, P., Gorynia, M., Nowak, J., \& Wolniak, R. (2019). EU Countries from Central and Eastern Europe, and the Investment Development Path Model: A New Assessment. Argumenta Oeconomica, 2(43), 385-406. https://doi.org/10.15611/aoe.2019.2.16

Trippl, M. (2013). Scientific Mobility and Knowledge Transfer at the Interregional and Intraregional Level. Regional Studies, 47(10), 1653-1657. https://doi.org/10.1080/00343404.2010.549119. 
Van Gigch, J. (1978). Applied General Systems Theory. London, UK: Harper \& Row.

Vashchuk, F.H. (Ed.). (2011). Intehratsiia v yevropeiskyi osvitnii prostir: zdobutky, problemy, perspektyvy: monohrafiia [Integration into the European Educational Space: Achievements, Problems, Prospects. A Monograph]. Uzhgorod, Ukraine: ZakDU. [in Ukrainian].

Vatamanyuk-Zelinska, U., \& Melnychenko, O. (2020). The effectiveness of financial and economic regulation of land relations in the context of stimulating entrepreneurial activity in the regions of Ukraine. Problems and Perspectives in Management, 18(3), 11-27. http://dx.doi.org/10.21511/ppm.18(3).2020.02

Yehorov, I. I. (2016). Systema kompleksnykh indykatoriv otsinky naukovo-tekhnichnoi ta innovatsiinoi diialnosti v konteksti protsesiv yevrointehratsii [A System of Complex Indicators for Evaluating Scientific, Technical and Innovative Activity in the Context of European Integration Processes]. Nauka innov., 12(4), 21-23. https://doi.org/10.15407/scin12.04.021 [in Ukrainian].

Zastempowski, M., Glabiszewski, W., Krukowski, K., \& Cyfert, S. (2020). Technological Innovation Capabilities of Small and Medium-Sized Enterprises. European Research Studies, 23(3), 460-474. 